NBER WORKING PAPERS. SERIES

INTERTEMPORAL LABOR SUPPLY: AN ASSESSMENT

David Card

Working Paper No. 3602

NATIONAL BUREAU OF ECONOMIC RESEARCH

1050 Massachusetts Avenue

Cambridge, MA 02138

January 1991

Presented at the World Congress of the Econometric Society, Barcelona Spain, August 1990. I am grateful to Dean Hyslop and John Penrod for outstanding research assistance, and to Robert Moffitt and my colleagues in the Industrial Relations Section for helpful comments and discussion. This paper is part of NBER's research program in Labor Studies. Any opinions expressed are those of the author and not those of the National Bureau of Economic Research. 
NBER Working Paper \#3602 January 1991

\section{INTERTEMPORAL LABOR SUPPLY: AN ASSESSMENT}

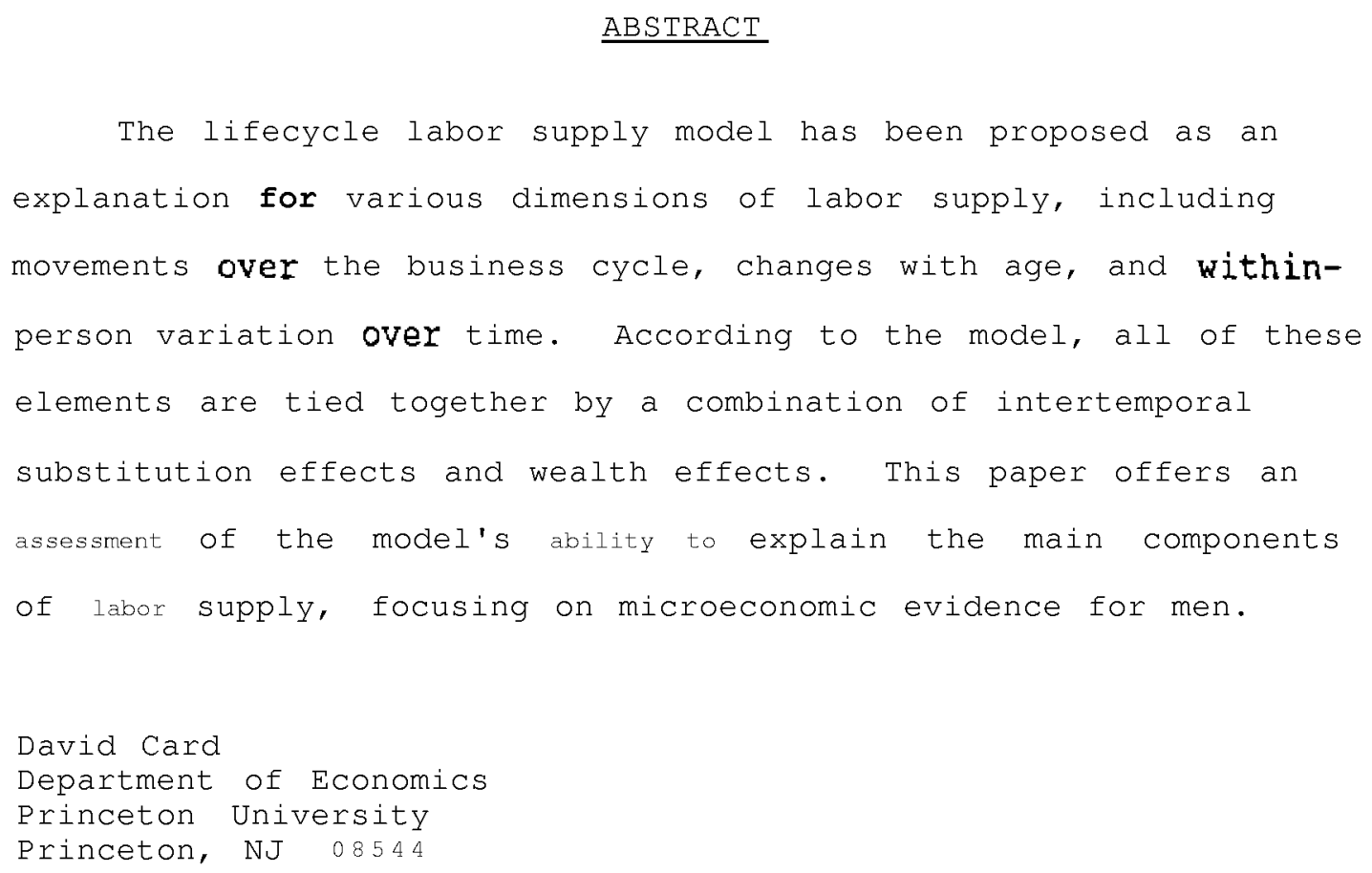




\section{Intertemporal Labor Supply: An Assessment}

The systematic study of intertemporal labor supply began only two decades ago. ${ }^{1}$ In a remarkably short time the lifecycle model of individual hours choice has moved to the forefront of both micra- and macroeconometric research. This paper begins with a look at the original questions that first lead to interest in the Iffecycle approach. I then present a selective review of the evidence on various dimensions of intertemporal labor supply. I limit my discussion to microeconometric studies of male labor supply. making no attempt at an exhaustive survey of even this branch of the literature. ${ }^{2}$ Rather, my goal is to offer an assessment of the success and/or failure of the lifecycle model in providing a useful framework for understanding the major components of individual labor supply

I conclude that the lifecycle labor supply literature sheds very little light on the questions that first generated interest in a lifecycle approach: what determines the shape of the lifecycle hours profile? how does labor supply respond to aggregate wage changes? what is the source of Idiosyncratic changes in year-to-year labor supply? Part of the reason for this stems from a tendency in the literature to concentrate on one aspect of intertemporal hours variation -- the response to wage growth along a known lifecycle trajectory .. and to ignore another, namely, the response to wage innovations that lead to revised expectations about future wage

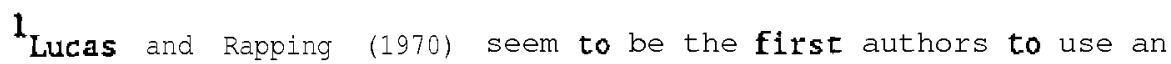
explicit intertemporal model to describe short and long run labor supply phenomena. although Mincer (1962) distinguished between the effects of short run unemployment and long run wage increases in explaining the behavior of female labor supply. (1986).

${ }^{2}$ Excellent surveys are available in Killingsworth (1983) and Pencavel 
rates. More seriously perhaps. much of the effort devoted to studying lifecycle labor supply has taken the position that average hourly earnings during the year is a "sufficient statistic" for hours choices within the year. There is considerable evidence against this narrow reading of the lifecycle model.

\section{The Questions}

A series of substantive questions motivated the original interest in 11fecycle labor supply. Lucas and Rapping (1970). following an original suggestion of Friedman (1976, pp.206-207), posited a lifecycle framework as a way to reconcile an elastic short-run labor supply curve with an inelastic or even backward-bending long-run labor supply curve. Lucas and Rapping's idea was to model cyclical hours variation as a response to a temporary wage change. Subsequently, much debate in the macroeconomics literature has focused on the size of this intertemporal wage elasticity. A second motivation for studying lifecycle labor supply arose from interest in human capital theory, and the recognition that the pattern of lifecycle hours is influenced by the pattern of lifecycle wage rates. This goal is clearly articulated by Heckman (1976, page S12), who notes that a model with endogenous labor supply can potentially reconcile differences in the lifecycle profiles of earnings and hourly wage rates. ${ }^{3}$

A related question is whether wage growth over the lifecycle can explain the parallel profiles of consumption and earnings. The simplest permanent income model predicts no systematic relation between earnings and

\footnotetext{
${ }^{3}$ Lucas and Rapping (1970. footnote 11) also noted in passing that
} their model had "...lifecycle as well as business-cycle implications." 
consumption. The finding that individuals with steeper lifecycle profiles of earnings have steeper lifecycle profiles of consumption has therefore bee" used as evidence of credit constraints or other impediments to an optimal lifecycle allocation (Thurow (1969), Ghez in Ghez end Becker (1975). Carrol and Summers (1989)). As Heckman (1974) pointed out, however. a model with endogenous labor supply can explain the parallel age profiles of consumption and earnings, if leisure and consumption are complements.

other questions have also emerged: what (if anything) can we conclude about the interpretation of measured unemployment (Ashenfelter and Ham (1979))? how does a lifecycle perspective affect the interpretation of the responses measured in the Negative Income Tax experiments? how doer a" intergenerational transfer system (such as social security) affect the hours of young and old workers? Finally, and perhaps fundamentally, how can we explain the enormous year-co-year variation in individual-specific labor supply that appears in virtually every available panel data set? The power of the lifecycle framework. and the extent of economists' faith In the model, are illustrated by considering a simple decomposition of individual labor supply into aggregate time effects, systematic age effects, permanent person-specific effects, and person-and-year specific effects. The lifecycle labor supply model has bee" proposed as a" explanation for all four components! Lucas and Rapping (1970) proposed that a 11fecycle model could explain aggregate year-to-year m ovements in labor supply (the "time effects" in a components-of-variance model).

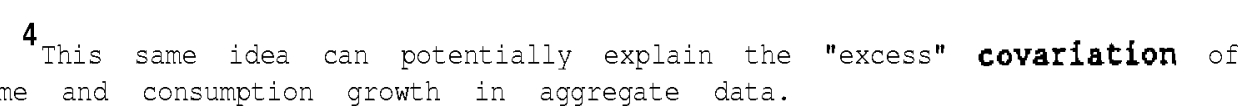
income and consumption growth in aggregate data. 
Heckman (1974, 1976), Ghez and Becker (1975), and others proposed that the lifecycle model could explain systemattc age effects in hours of work, and also differences across people in their amount of market work over the lifecycle (1:e. the person-specific constants), Finally, models used by Macurdy (1981), Altonji (1986) and others link person-and-year-specific changes in hours to the corresponding changes in wages.

\section{The Basic Model}

A prototypical lifecycle labor supply model begins with a timereparable utility function defined over consumption ( $c_{i t}$ ) and hous of work ( $h_{1 t}$ ) of individual 1 in each of a sequence of periods $t=0,1,2, \ldots$

$$
\Sigma_{t} \beta^{t} \mathrm{U}\left(c_{i t}, h_{1 t}, a_{i t}\right)
$$

Here, $\beta-(1+\rho)^{-1}$ measures subjective time discounting and $a_{i t}$ is a sequence of "taste shifters" that capture heterogeneity across individuals and over time. In models with uncertainty, preferences are assumed to be additive over states and time (with the same U( ) function) so that the consumer's objective function is simply the expectation of (1). conditional o" current information.

The second element of the model is the intertemporal budget constraint. which describes the change in the value of assets ( $A_{i t}$ ) between periods:

$$
A_{1 t+1} / P_{t+1}=\left(1+r_{t}\right)\left(A_{t} / P_{t}+w_{1 t} h_{1 t} \cdot c_{t}\right)
$$

Here, $P_{t}$ is the pice of consumption goods in $t, r_{t}$ is the real interest rate in period $t$ (assumed to be known). and $w_{1 t}$ is the real wage of individual 1 for hours woked in period $t$. 
An interior solution for maximization of the expectation of (1),

subject to (2) and a" appropriate terminal condition on assets. is

characterized by first-order conditions for consumption and hours in perlod

$t$, together with a" intertemporal optimality condition for the marginal

utility of wealth in period $t\left(\lambda_{1 t}\right):^{5}$

$$
u_{c}\left(c_{1 t}, h_{1 t}, a_{1 t}\right)=\lambda_{1 t}-0
$$

$$
u_{h}\left(c_{i t}, h_{1 t}{ }^{a}{ }_{i t}\right)+w_{1 t} \lambda_{1 t}=0
$$

$$
\lambda_{1 t} \cdot \beta\left(1+I_{t}\right) E_{t}\left[\lambda_{1 t+1}\right]=0 \text {. }
$$

Equations (3a) and (3b) can be solved for consumption and hours in terms of $w_{\text {it }}$ and the current marginal utility of wealth. It is conventional to refer to the implied solution for hours as the "intertemporal labor supply function". With a" appropriate transformation of the taste shift variable $a_{t}$, write the log-linear approximation ${ }^{6}$ of this function as:

$$
\log h_{i t}=a_{i t}+\eta \log w_{i t}+6 \log \lambda_{i t} .
$$

The parameter $\eta$ represents the elasticity of hours in period $t$ with respect to wages in $t$, holding constant the marginal utility of wealth. Following the literature. I shall refer to $\eta$ as the intertemporal substitution elasticity. This elasticity is necessarily positive. and is strictly greeter than the (Hicksian) compensated labor supply elasticity associated with the same preferences. if leisure is a normal good. The parameter 6 represents the elasticity of hours with respect to the marginal utility of

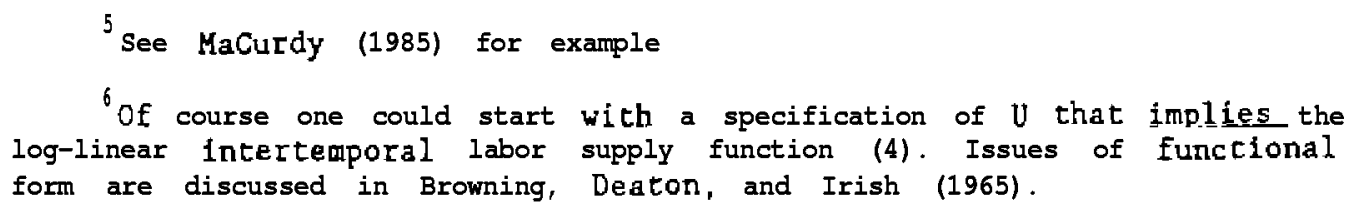


wealth, and also must be positive if leisure is a normal good. The two

elasticities are related by the simple condition

$$
\eta-\delta-\frac{c_{1 t}}{w_{1 t^{b}}} \cdot \frac{\log c_{1 t}}{a \log w_{1 t}}
$$

If consumption is independent ôf wages, holding constant the marginal

utility of wealth (as is imolicitly assumed in the permanent income

consumption model), then $\boldsymbol{\eta}=6$.

Note the convenient form of the lifecycle labor supply function (4).

As a consequence of the additive structure of preferences, the effects of

asset income and future wages are completely summarized in the value of

$\lambda_{16}$. With perfect foresight and constant real interest rates, (3a) implies

that $\lambda_{1 \boldsymbol{t}} \cdot \boldsymbol{\lambda}_{\mathbf{1 0}} \mathbf{g}^{\mathbf{t}}$, where $\boldsymbol{g}$ is greater or less than 1 depending on the gap

between the real interest rate and the rate of time preference $\rho$. In this

case, apart from taste changes and a geometric trend. the lifecycle profile

of labor supply is completely determined by the profile of wages.

The implications of the lifecycle model under uncertainty are most

easily seen by combining equation (3c) with equation (4) to describe the

change in hours between periods $t-1$ and $t$ :

(5) $\Delta \log h_{1 t}=\Delta a_{i t}+\eta \Delta \log w_{1 t} \cdot \delta \cdot\left(r_{t-1} p\right)+\delta \phi_{1 t}+\delta \xi_{1 t}$

where $\phi_{\mathbf{i t}} \cdot \log \lambda_{\mathbf{1 t}} \cdot \mathrm{E}_{\mathbf{t}-\mathbf{1}} \log \lambda_{\mathbf{1 t}}$ is the one-period-ahead forecast error

in the logarithm of the marginal utility of wealth. and

$\boldsymbol{\xi}_{1 \mathbf{t}}-\mathrm{E}_{\mathbf{t}-\mathbf{1}}\left[\exp \left(\boldsymbol{\phi}_{\mathbf{i t}}\right)\right] .^{7}$ The letter term is a constant if the (prior)

distribution of $\boldsymbol{\phi}_{\mathbf{i t}}$ is constant. Thus, the change in labor supply consists

of a component due to changes in tastes $\left(\mathbf{~ a ~ a ~}_{\mathbf{i t}}\right)$, a component due to

${ }^{7}$ I have simplifled (5) slightly using the approximations $\log (1+p)-p$

and $\log \left(1+r_{t}\right)-r_{t}$. 


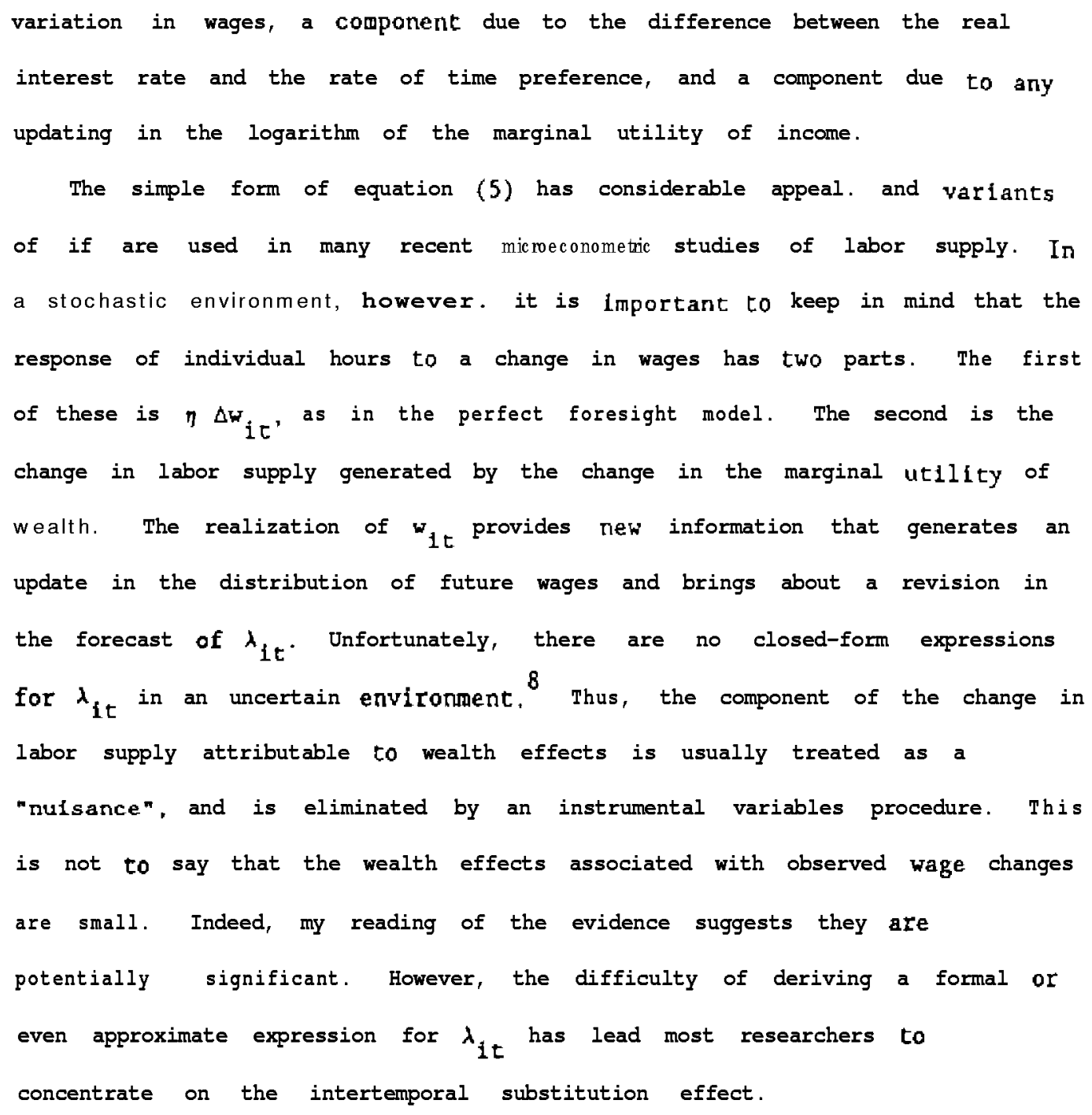

${ }^{8}$ In fact, closed form expressions for $\lambda$ under perfect foresight are not easily obtained. One case chat can be solved uses an LES-form for the within-period utility function $U$. See Ashenfelter and Ham (1979). 
III. Empltical Implicattions and Evidence

a. The Lifecycle Profile of Hours.

The first and most direct implication of the lifecycle mod.1 concerns

the shape of the lifecycle hours profile. As pointed out earlier, with

perfect foresight and constant real interest rates. the model implies that

the lifecycle profile of hours consists of a taste component, $a$ trend, and

a component that is strictly proportional to wages. The presence of

uncertainty adds other components with mean zero over a large sample of

lifecycles. To see this, re-write the lifecycle labor supply function as:

(4.3) $\log h_{i t}-a_{i t}+\eta \log w_{i t}+\delta\left(\log \lambda_{i 0}+\sum_{j=0}^{t}\left(\rho \cdot I_{t-j-1}+\phi_{i t-j}\right)(\right.$

$=E O \log h_{i t}+\eta\left(\log w_{i t}-E O \log w_{i t}\right)$

$$
\text { - } \delta\left|\sum_{j-0}^{t-1}\left(\mathbf{r}-\mathbf{r}_{t-j-1}+\phi_{i t-j}\right)\right|
$$

where EO denotes expectations at the beginning of the lifecycle, and $\mathbf{r}$ is

the expected real interest rate in period 0 (assumed to be constant).

Hours at age $t$ differ from hours planned at the beginning of the lifecycle

by a term representing the forecast error in wages, plus another

representing the cumulative forecast errors in interest rates and the

marginal utility of income. Over a large sample of lifecycles (spanning

different periods of calendar time), the estimated age profile of lifecycle

hours therefore converges to the mean of the planned profiles. 9

The typical shapes of the lifecycle profiles of wages and hours for male workers are illustrated in Figures 1 and 2 . The underlying data for

9 Obviously, it may not be possible to recover an unbiased estimate of the planned lifecycle profile of hours from a sample of individuals in the same cohort, since these individuals share the same aggregate-level shocks in each year of their life. 
these figures are taken from the 1977-1989 March Current Population Surveys

(CPS), and pertain to annual hours and average hourly earnings (annual

earnings divided by annual hours) for calendar years 1976-88. 10 Figure 1

shows annual averages of $\log$ wages for 6 single-year age cohorts. Each

distinct line in the figure tracks the wage profile of a single cohort over

the 13 year sample period. Figure 2 shows the corresponding profiles of

average annul hours.

The data in Figure 1 suggest char successive cohorts face similar

expected wage profiles: real wages rise quickly between the ages of 20 and

30. and then grow more slowly to a peak around age 50. Nevertheless. there are obvious year effects in average hourly earnings. 11 and important cohort effects, During the 1980's, later cohorts tended to earn lower real wage rates than earlier ones. This negative wage growth provides a" interesting opportunity to test Lewis' (1956) influential interpretation of the trend toward lower hours of work during the first half of the 20 th century. Levis (1956, p. 197) argued that the decline reflected a" income effect, driven by higher average wages for successive cohorts of workers. If this interpretation is correct, one should detect a" increase in hours for the mast recent cohorts.

${ }^{10}$ The samples for each year consist of men age 16-70, excluding those who are classified as self employed and those with allocated wage and salary earnings. Individuals who report positive wage and salary earnings. positive weeks of work, and positive usual hours per week for the previous year are counted as working. Individuals who were working and who report average hourly earnings less than $\$ 1.00$ or greater than $\$ 75$ (in 1983 dollars) are deleted from the sample. The sample sizes in each year range from 36,000 to 42.000 .

${ }^{11}$ Average real wage rates declined sharply between 1979 and 1981 . For the youngest cohort in Figure 1, this effect appears as a slowdown in the rate of growth of wages. For older cohorts, real wages actually declined. 
The lifecycle profiles of hours in Figure 2 have a rather different shape than rhe profile of wages. Per-capita hours of work reach their peak in the early $30 \mathrm{~s}$. are roughly constant co age 40 , fall slightly to age 50, and then decline sharply. The pattern of hours among chose who actually work is similar. reaching a peak of about 2100 hours at age 30 , remaining arable to age 50, falling to 1900 hours at age 60, and then declining sharply. The growth in hours at the beginning of the lifecycle coincides with a gradual withdrawal from school. Thirty percent of all 20 year olds in the March CPS (1977-89) report their main activity in the previous veek as "in school". This fraction falls to 11 percent by age 23 and to 2 percent by age $30 .^{12}$ Much of the decline in per-capita hours at the other end of the lifecycle reflects withdrawal from the labor force. By age 62, only 50 percent of men are still working any hours. Lifecycle patterns in enrollment and employment probabilities are illustrated in Figure 3, which graphs the average probabilities by age for men in the 13 year CPS sample. 13

The hours profiles in Eigure 2 indicate strong year effects, with all cohorts showing a downturn in hours in 1982. In contrast to the profiles of wages. however, the hours profiles of the younger cohorts are not systematically different from those of the older cohorts. Thus, there is no evidence for the inter-cohort income effects underlying Lewis' explanation for the earlier decline in per-capita hours.

\footnotetext{
${ }^{12}$ The CPS does not ask "weeks in school" during the previous year, or give any breakdown of hours per week into work and school time.

${ }^{13}$ The emoloyment and enrollment rates in Figure 3 are not adjusted for any cohort effects. 'However, adjusted races are very similar.
} 
Ho" well does the lifecycle model explain the lifecycle profile of hours? Between the ages of 20 and 30, "ages grow by 40-45 percent, per capita annual hours grow by 55 percent, the employment rate grows by 10 points, and hours conditional on working grow by 45 percent. Between the ages of 30 and 50, "ages rise another $10-15$ percent. conditional hours are constant. and the probability of working falls 5 points. Finally, between the ages of 50 and 60 , "ages fall 5 percent, conditional hours fall 5-10 percent, and the emoloyment rate falls by over 20 points. Clearly, the degrees of "curvature" in the lifecycles profiles of "ages and hours are different. Of course this does not refute the lifecycle model, because tastes may vary systematically with age. and it is also possible that the Intertemporal substitution elasticity varies with the number of hours norked. ${ }^{14}$

A stronger test is provided by the data in Figures 4 and 5, which represent "age and conditional hours profiles for men in 3 education classes: $0-0$ years of schooling. exact1y 12 years of schooling, and 16 or more years of schooling. ${ }^{15}$ Between the ages of 30 and 50 the "age profiles of these three groups differ dramatically. Wages of college graduates grow some 40 percent, "ages of highschool graduates grow about 20 percent. and wages of individuals with minimal schooling grow only 10 percent. However,

${ }^{14}$ The "age profiles are also potentially biased estimates of the "age profiles for the "hole population, since we only observe "ages for workers. One way to evaluate the size of this bias is to assume that "ages for those not working would be at some lower bound (say. the minimum "age) and then to re-calculate the average "age. This procedure suggests that rhe bias in the "age profiles up to age 50 is trivial.

${ }^{15}$ These profiles ate estimated age coefficients from regressions of average log wages and average log hours on age effects, year effects, and a set of broad (10-year interval) cohort effects. 
for all three groups. hours (conditional on working) are constant between age 30 end 50. In fact, the hours profiles of the different education

groups are very similar. To explain these data with a simple lifecycle

model requires a fairly elaborate set of taste parameters. ${ }^{16}$ A simpler

interpretation is that the shape of the wage profile bears no causal

relation to the shape of the hours profile.

It also is interesting to compare the three education classes in terms

of their average lifetlme hours and average lifetime wages. For

simplicity, assume that individuals with $0-8$ years of schooling begin work

at age 16, vhile highschool graduates begin work at 18 and college

graduates begin work at 22. 17 Then average hours worked per year between

the ages of 16 and 69 for the three education groups are es follows:

Hours Kear

Hours/Year. if working

$0-8$

12

$16+$
1265

1537

1638
1756

1809

1833

Given the wage differentials between the 3 groups. these data suggest that

higher lifetime wages are associated with higher lifetime hours. This

${ }^{16}$ one could also appeal to models with endogenous human capital accumulation. Evidence presented by Holtz-Eakin, Newey and Rosen (1988) however, indicates that legged hours have no influence on future wages.

This seems to rule out simple capital accumulation models.

17 These assumptions clearly understate the total labor supply of the more-educated workers. First, many students work part-time or part of the year. Second, actual time spent in school is arguably closer to work than lelsure. 


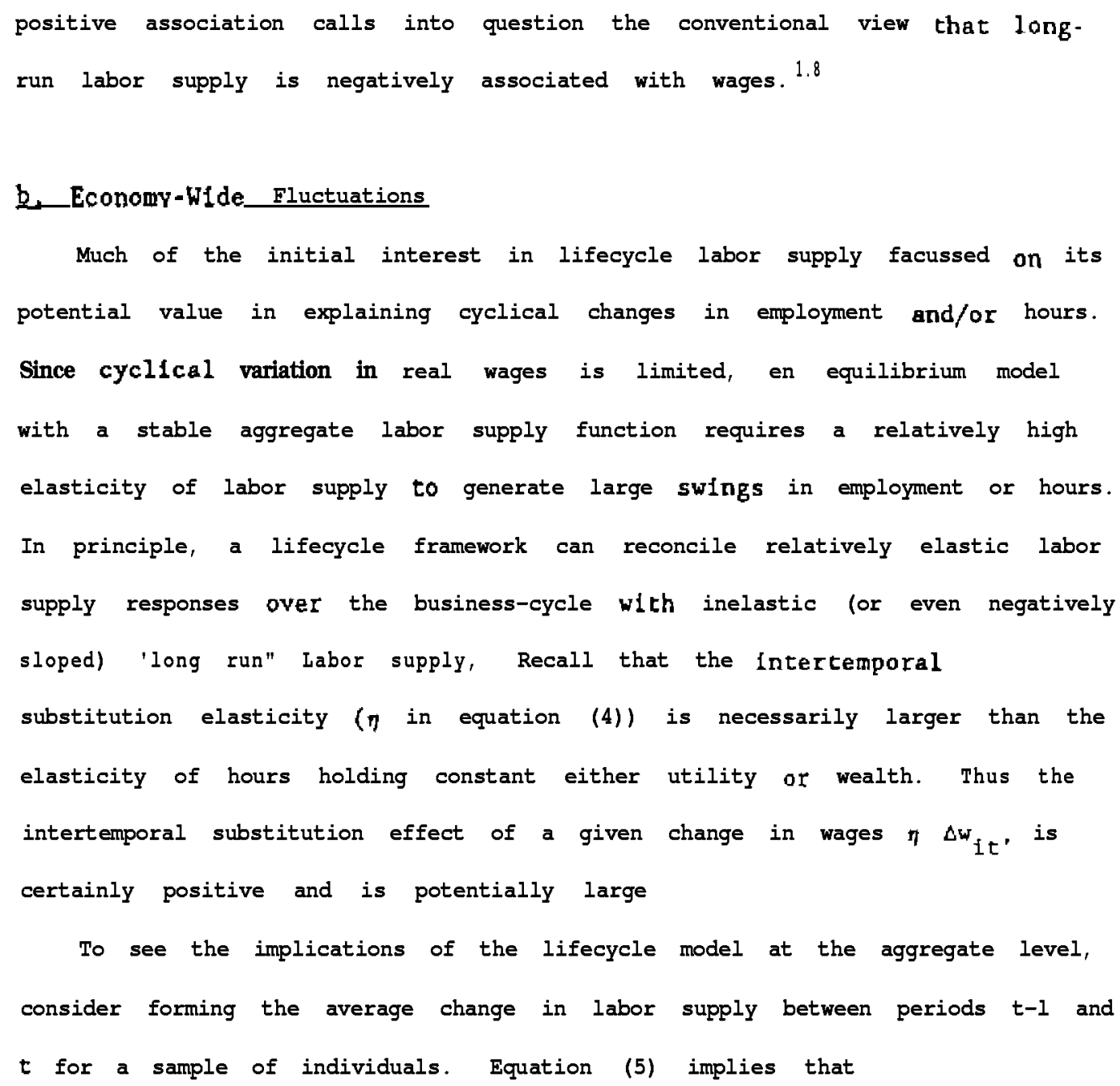


where $\Delta \log$ ht represents the average change in log hours in the sample,. $\mathbf{\Delta a}_{t}$ represents the average change in the taste variable, $\Delta \log _{\mathbf{c}}$ represents the average change in $\log$ wages. and $\phi_{t}$ represents the mean of the forecast errors in $\log \lambda_{1}$. In principle it is possible to estimate (5a) on aggregate-level data. Something like this is actually carried out in Lucas and Rapping (1970). Altonj1 (1982). and Mank1w, Rotemberg and Summers (1985). Here I vish to discuss the implications of (5e) for the "time effects" that emerge in mlcroeconometrlc studies of labor supply. This idea was suggested by Ashenfelter (1984) and is pursued by Angrist (1989. 1990).

Ashenfelter (1984) observed that aggregate changes in labor supply for a fixed cohort take a particularly simple form if (i) there are no aggregate components of taste variation. (ii) the real interest rate equals the rate of rime preference, and (iii) individuals have perfect foresight. In this case equation (5a) reduces to

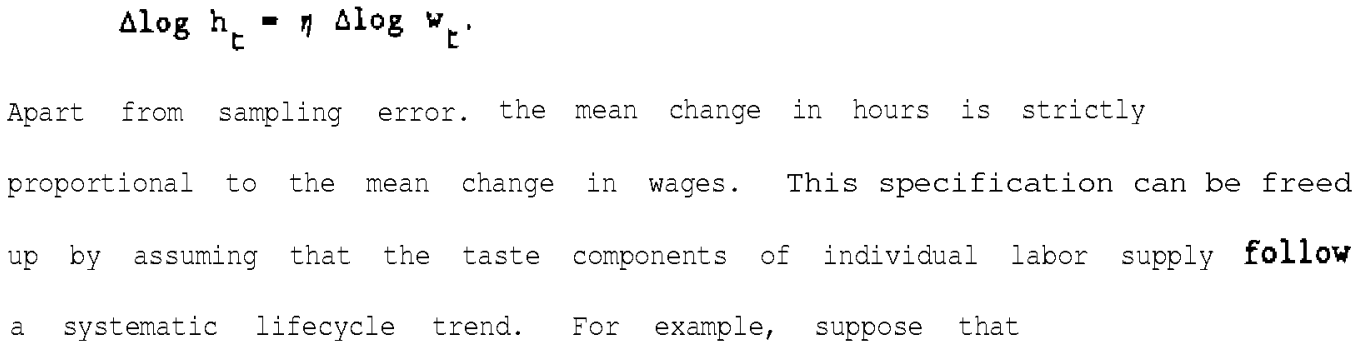

$$
a_{1 t}-a_{1}+b \text { Age }_{i t}+c / 2 \text { Age }_{i t}^{2}
$$

where $\mathbf{a}_{\mathbf{1}}$ is a permanent person-specific component of tastes, Age $\mathbf{i t}_{\text {denotes }}$ the age of individual $i$ in period $t$, and $b$ and $c$ are common population parameters. Then equation (5a) implies

$$
\Delta \log h_{t}-b \cdot c / 2+c \cdot t+\eta \Delta \log w_{t}
$$


Since (by assumption) the only aggregate components of labor supply are taste and wage variation. equation (6) should fit the mea" changes in hours end wages exactly. apart from sampling error in the estimated means.

Therefore, as the number of individuals in the panel increases, the $\mathrm{R}^{2}$ associated with (6) should tend to unity. ${ }^{19}$

Fstimates of this equation are presented in Angrist (1989) using the means of wages and hours for a panel of males in the Panel study of Income Dynamics (PSID). 20 corresponding estimates based on cohort-level data from consecutive CPS samples are presented in Angrist (1990). In analyzing the CPS samples, Angrist (1990) divides the available data Into two subsamples -- 1963-74 and 1975-87 -- and follows me" age 25-50 in 1964 in the first subsample, and me" age 25-50 in 1976 in the second. Angrist's estimates qf the Intertemporal substitution elasticity (with their estimated standard errors in parentheses) are as follows:

${ }^{19}$ The se implications are unchanged if one adds a person- and timespecific component of taste variation to the model.

20 Actually, Angrist estimates the aggregated labor supply function in level form. 


\begin{tabular}{|c|c|c|c|c|}
\hline & \multicolumn{4}{|c|}{ Sample: } \\
\hline & PSID & $1969-79$ CPS & $1963-74$ & CPS 1975-87. \\
\hline \multicolumn{5}{|c|}{ Preference Trend: } \\
\hline None & & $\begin{array}{l}-.13 \\
(.04)\end{array}$ & $\begin{array}{l}-.01 \\
(.01)\end{array}$ & $\begin{array}{l}.61 \\
(.09)\end{array}$ \\
\hline Linear & & $\begin{array}{l}.56 \\
(.12)\end{array}$ & $\begin{array}{l}.2 s \\
(.08)\end{array}$ & $\begin{array}{l}.58 \\
(.09)\end{array}$ \\
\hline Quadratic & & $\begin{array}{l}.63 \\
(.21)\end{array}$ & $\left\{\begin{array}{l}.04 \\
(.10)\end{array}\right.$ & $\begin{array}{l}.94 \\
(.14)\end{array}$ \\
\hline
\end{tabular}

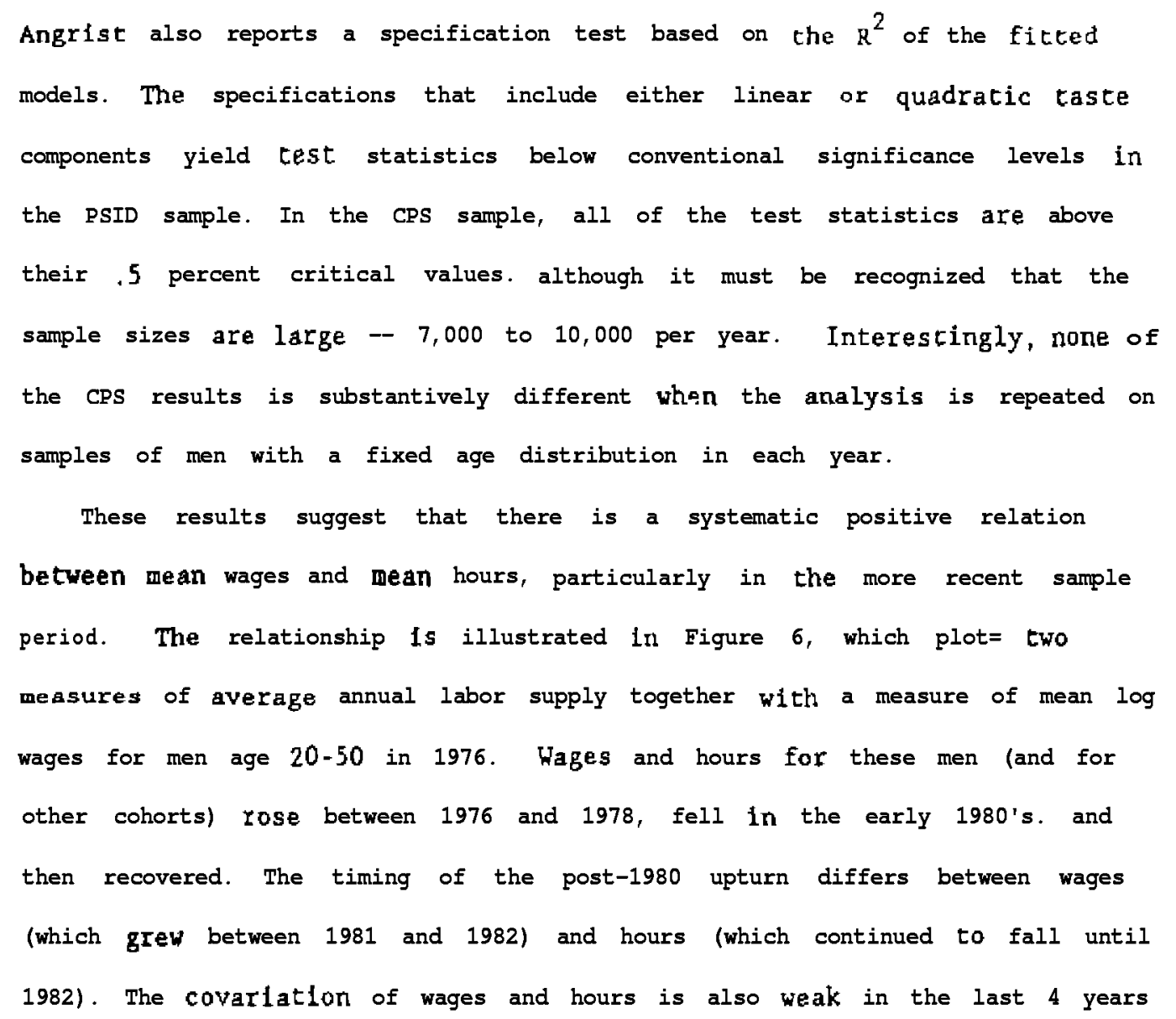


of the data. Nevertheless. wage and hours changes from 1976 to 1988 are very highly correlated

Should we conclude that Intertemporal labor supply does a good job of explaining the time effects that emerge in an microeconometrlc model? Hy belief is that such a conclusion is premature. The reason is that the assumption of perfect foresight regarding the aggregate changes that occurred in the late 1970's and early 1980's is surely false. In the 3 decades before 1976, average real wages in the U.S. economy grew fairly steadily at $2-3$ percent per year. 21 After 1975. real wage growth essentially stopped. This sharp downward adjustment in trend, coupled with the actual losses in real wages in the early 1980s, suggests that many Individuals suffered unexpected reductions in their lifetime wealth According to the Lifecycle model, these changes should have affected hours decisions, and therefore should be modelled in the aggregate labor supply equation.

The difficulty is that very little is known about the evolution of the marginal utility of Income or the size of the wealth elasticity 6 . One approach is to write down a" intuitively plausible or econometrically convenient model for $\boldsymbol{\lambda}_{1 t}$. For example. Lucas and Rapping (1970) specified a labor supply function of the form

(7) $\quad \log h_{1 t}=a_{1 t}+\eta\left(\log w_{1 t} \cdot \log w_{1 t}^{*}\right)+\theta \log w_{1 t}^{*}$

where

$$
\log w_{i t}^{*}-\sum_{j=0}^{T=t} b_{j} E_{t} \log w_{t+j} \quad\left(\Sigma b_{j}-1\right)
$$

21 Between 1947 and 1976, for example, real average hourly earnings of "on-supervisory workers rose at a" average annual rate of 2.38 percent. 
Th1s is equivalent to replacing $6 \log \lambda_{\text {tt }}$ with $-(\boldsymbol{\eta}+\boldsymbol{\theta}) \log \mathbf{w}_{\mathbf{1 t}}$ in the labor supply function (4). 22 As Altonj1 and Ashenfelter (1980) pointed out, the labor supply effects of aggregate wage changes in this model depend critically on the degree of persistence in innovations to the real wage. I" fact, it is difficult to reject the hypothesis that the aggregate real wage rate is a random walk with drift. If workers assume that the "year effects" in individual wages have the same property. then the labor supply effect of a change in the aggregate component of wages depends only on the "long run" elasticity $8 .{ }^{\mathbf{2 3}}$ If this is negative (as Lewis (1956) and many subsequent authors have assumed) and if individuals expect aggregatelevel changes in real wages to persist indefinitely (as is perhaps true for changes in economy-wide real wage rates) then the predicted correlation between the year effects in hours and wages from a panel of individual data is negative!

The only evidence in the microeconometric literature pertaining to the sign of the "long run" labor supply elasticity (i.e., the elasticity of hours with respect to a parallel shift in wage profiles) is from MaCurdy (1981, 1985). Macurdy (1985) suggests a less restrictive specification for the marginal utility of income than Lucas-Rapping:

22 One can derive a" intertemporal labor supply function that is approximately equivalent to the Lucas-Rapping function (with $\boldsymbol{\theta}-0$ ) using the within-period preference function

$$
U(c, h)=c \cdot a h^{(1+\eta) / \eta} .
$$

However, this is only valid in the absence of uncertainty.

${ }^{23}$ To see this, decompose $\log w_{\text {into a }}$ inermanent person effect. a year effect $\mathbf{v}_{t}$, and a person and year specific effect. and suppose

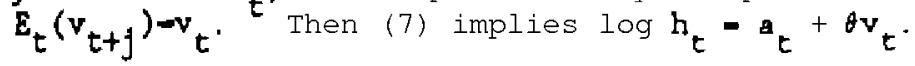




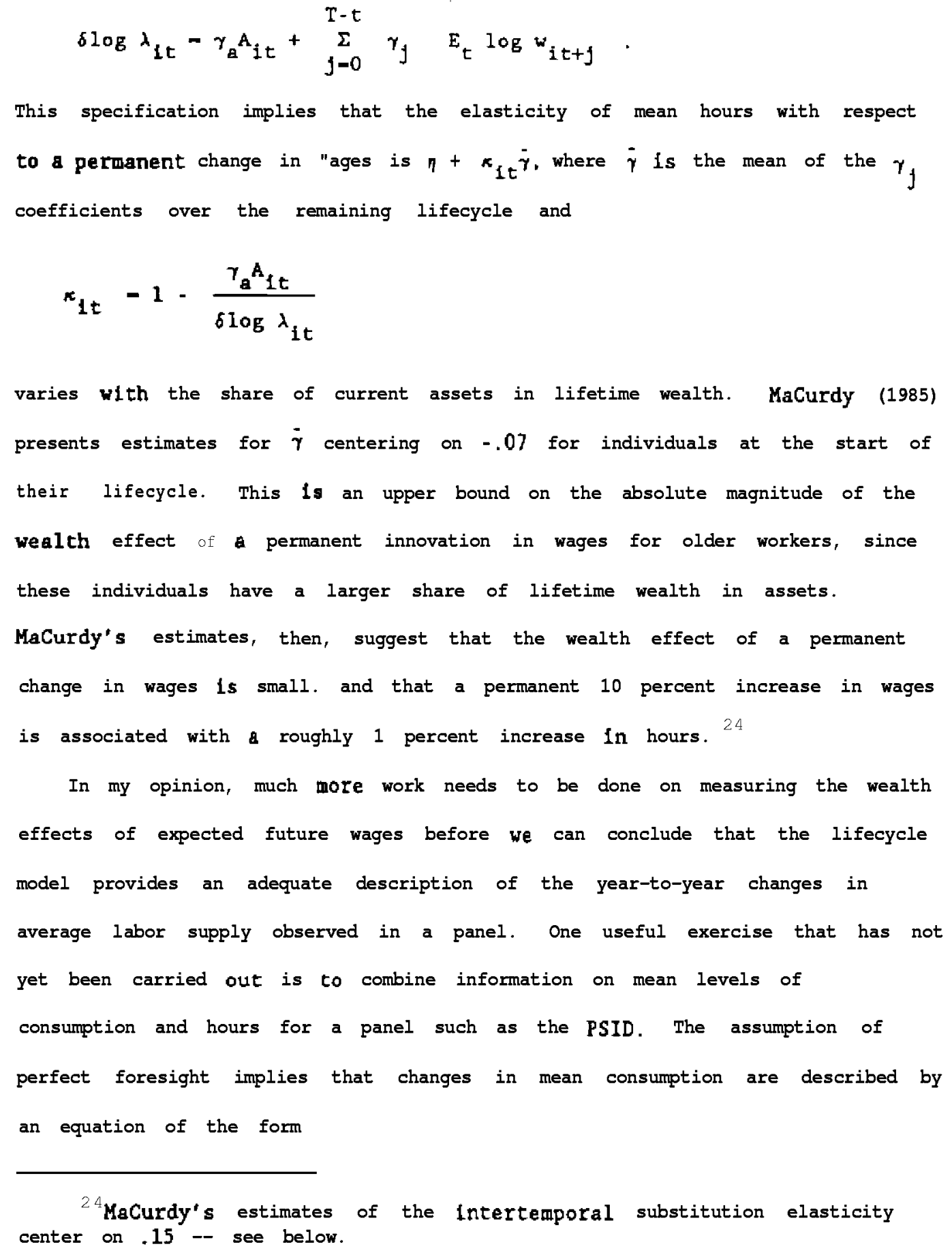




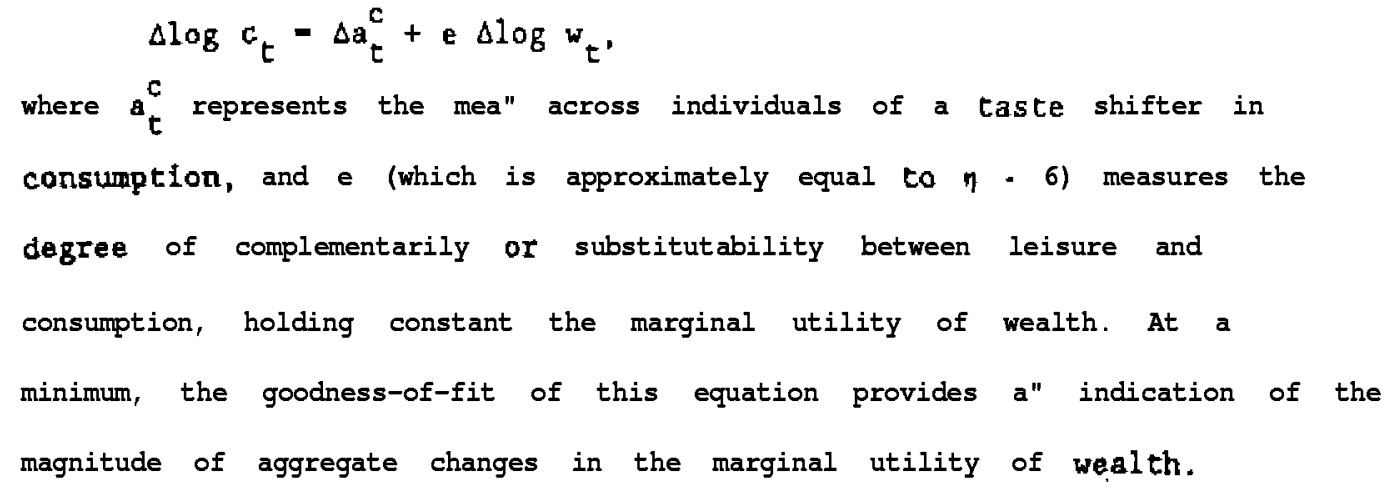

\section{c. Individual-Speclfic_Comp_ents_of Ware and Hours Variation}

In addition Co its implications for the age and time effects in microeconometric studies of labor supply, the lifecycle model offers a potential explanation for individual and period-specific hours variation Specifically. suppose that Individual log wages are determined by a" equation of the form:

$$
\log w_{1 t}=w_{1}+v_{t}+u_{1 t}
$$

where $\omega_{i}$ is a person-specific constant, $v_{t}$ is an aggregate effect, and $u_{i t}$ is a person and time-specific effect. Then equation (5) implies

(9) $\Delta \log h_{1 t} \cdot \Delta \log h_{t}=\left(\Delta a_{1 t} \cdot \Delta a_{t}\right)+\eta u_{1 t}+\left(\phi_{1 t} \cdot \phi_{t}\right)$.

The person-specific component of hours varlation in period $t$ consists of person-specific taste variation, a person-specific intertemporal substitution effect $\eta u_{1 t}$, and the difference between the person-specific forecast error in $\log \lambda_{1 \tau}$ end the average forecast error over the entire sample.

The person-specific component of year-to-year changes in labor supply is large. For example, Altonjl and Paxson (1985) estimate that the cross * sectional standard deviation of the change in log annual hours between 


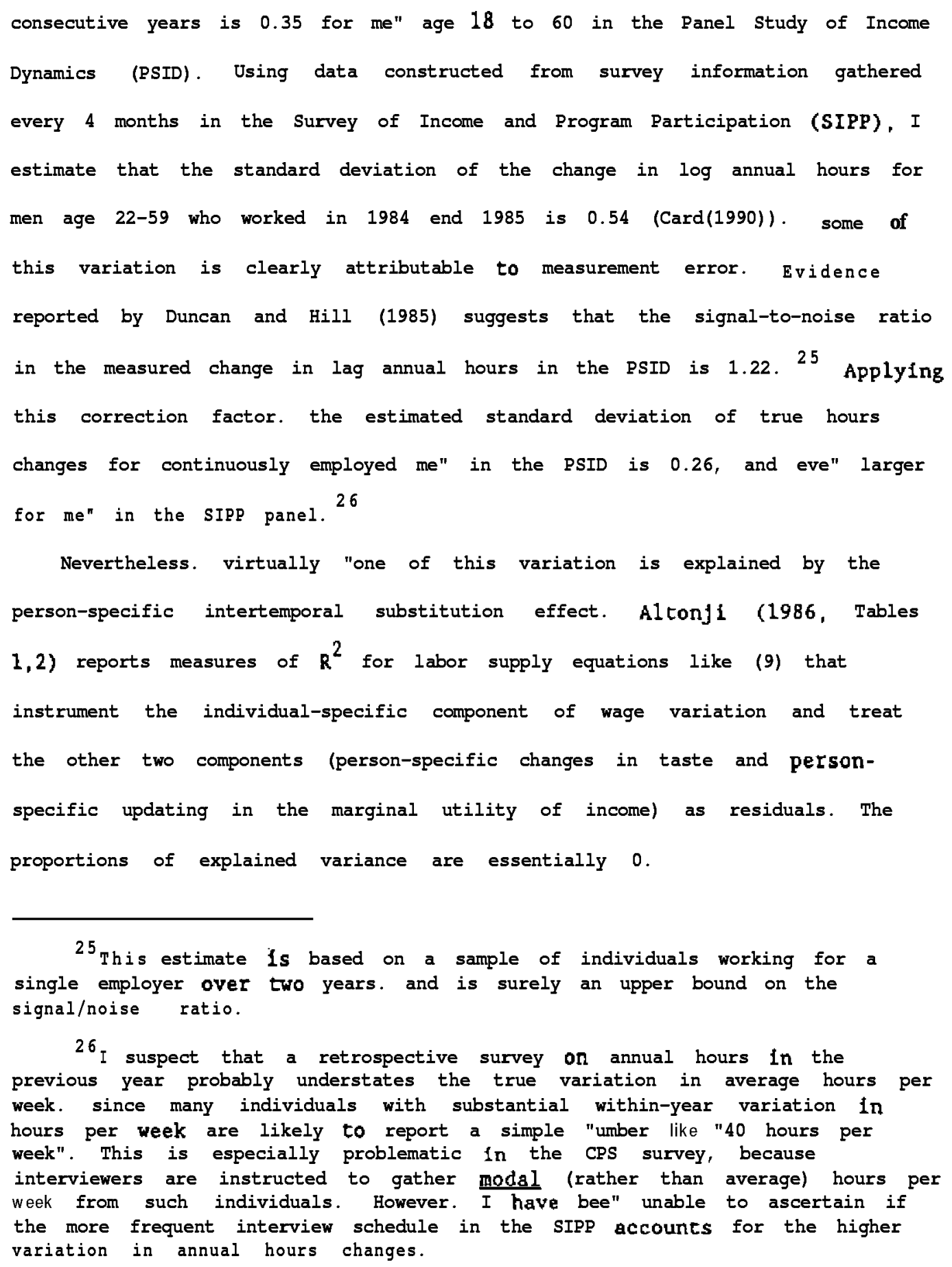


One reason for this low proportion of explained variance is the very small magnitude of the estimated intertemporal substitution elastlcitles that typically emerge from microeconometric studies. 27 MaCurdy's (1981) estimates from the PSID range from 0.10 to 0.45 . Altonj1's (1986) estimates, also based on PSID data, range from 0 to 0.5 , with the more precise estimates clustered near the bottom of this interval. A similar range of estimates emerges from other studies of the PSID, including Ham (1986), and from the detailed study of cohort-level data from the British Famfly Expenditure Survey by Browning. Deaton, and Irish (1985). Taken together, the literature suggests that the elasticity of intertemporal substitution is surely no higher than 0.5 , and probably no higher than 0.20. Given such small elasticities, the component of individual hours changes attributable to intertemporal substitution effects is tiny. This leads to the question of whether there is any explanation for individual-specific hours variation. One source of systematic hours variation that is described by the labor supply model, but ignored in most studies, is idiosyncratic variation in the marginal utility of wealth. Some of this is potentially explainable by observed wage changes, particularly if person-speciflc wage innovations are highly persistent. To collect some evidence on the persistence of idiosyncratic wage shocks. I fit a very simple version of the components-of-variance model (8) to data on log wages for men in the PSID. Specifically. the model assumes that the measured $\log$ wage of individual 1 in period $t$ is given by:

27 One exception is MaCurdy's (1983) study using a sample of males in the control group of the Denver Income Maintenance Experiment. MaCurdy does not parameterize preferences $1 n$ such a way as to imply a constant Intertemporal substitution elasticity. However. his estimates imply that the Intertemporal elasticity is high: In the neighborhood of 2.0 . 


$$
\log w_{1 t}=w_{1}+v_{t}+u_{1 t}+\mu_{1 t}
$$

where

$$
\begin{aligned}
& u_{1 t}-\alpha u_{1 t+1}+\zeta_{1 t^{\prime}} \\
& \operatorname{var}\left(\zeta_{1 t}\right)-\sigma_{t^{\prime}}^{2} \operatorname{cov}\left(\zeta_{1}, \zeta_{1 t}\right)-0, t-s_{1} \\
& \operatorname{var}\left(\omega_{1}\right)=\sigma_{\omega^{\prime}}^{2} \quad \operatorname{var}\left(\mu_{1 t}\right)-\sigma_{\mu}^{2} \\
& \operatorname{cov}\left(\zeta_{1 t}, \omega_{1}\right)-\operatorname{cov}\left(\zeta_{1 t}, \mu_{1 t}\right)=\operatorname{cov}\left(\omega_{1}, \mu_{1 t}\right)-0 .
\end{aligned}
$$

In this model the person- and period-specific wage shock consists of two components: a first-order serially correlated component with a time-varying variance $\left(u_{1 t}\right)$, and a serially uncorrelated component $\left(\mu_{1 t}\right)$. One interpretation of the latter is as a white noise survey measurement error. However, this is Indistinguishable from a "purely transitory" wage component. I have fit this model (using minimum distance techniques) to the covarlance matrix of Individual wage data for 1374 men who worked in each year between 1969 and 1979. 28 For convenience in estimation I have used the wage data for 1971-78 only.

The covariances of the wage data are presented in Table 1 , together with their estimated standard errors and the average autocovarlances at each lag. The autocorrelations decline from 0.78 (et lag 1) co 0.59 (at lag 7). There is some evidence of nonstatlonarity in the data, with the variances and covariances rising in the last years of the panel. The sample excludes 105 individuals who otherwise meet the data requirements but who are eliminated by virtue of reporting an hourly wage less than $\$ 0.75$ or greater than $\$ 100$ (in $1967 \$$ ) in one or more years. When these

$$
{ }^{28} \text { Specifically. I estimated the vector of parameters } \beta \text { by minimizing }
$$
(I. - $f(\beta))^{\prime} \mathrm{V}^{-1}(\mathrm{~m}-\mathrm{f}(\beta))$, where $\mathrm{m}$ is the vector of 36 second moments of the wage data, $f(\beta)$ is the vector of fitted moments, and $v$ is the estimated variance matrix of the second moments. 


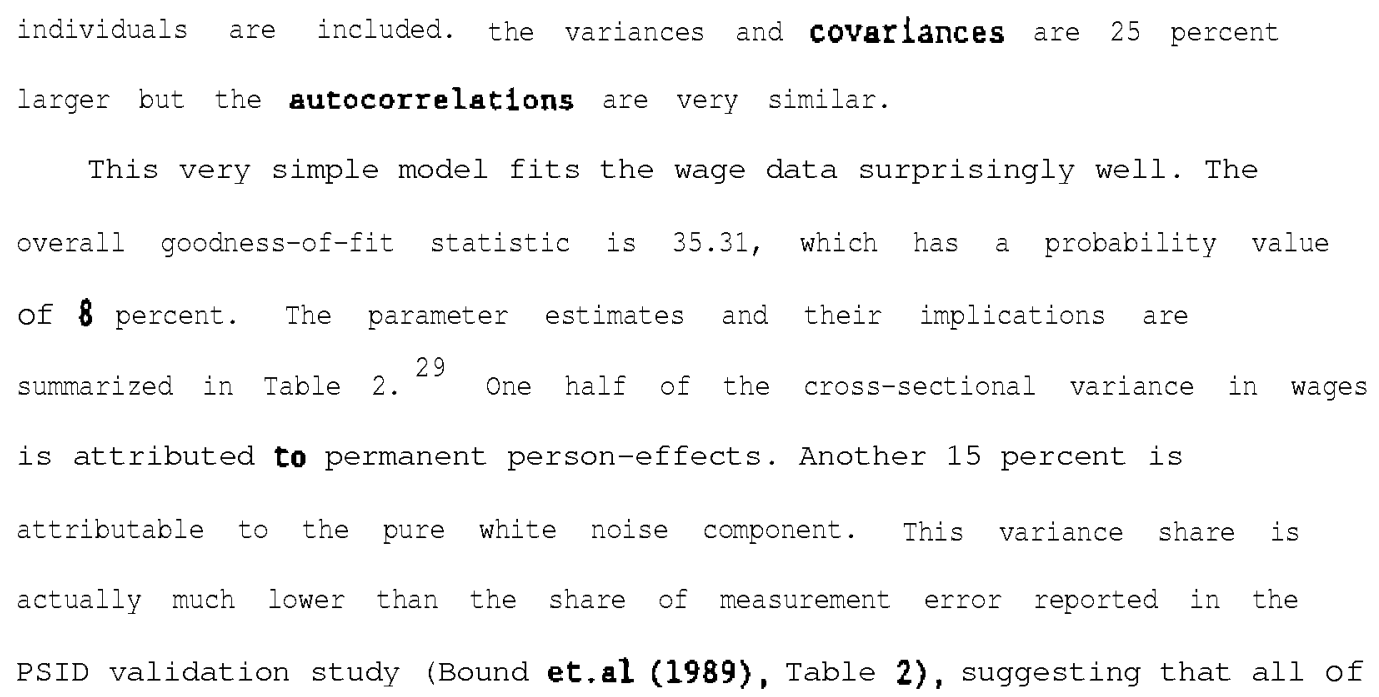

${ }^{29}$ There are a total of 12 parameters in the model, including the 8

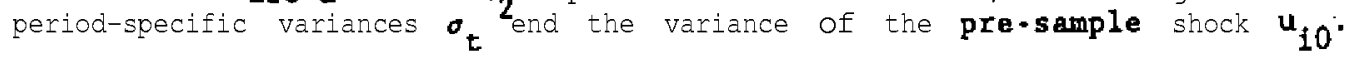




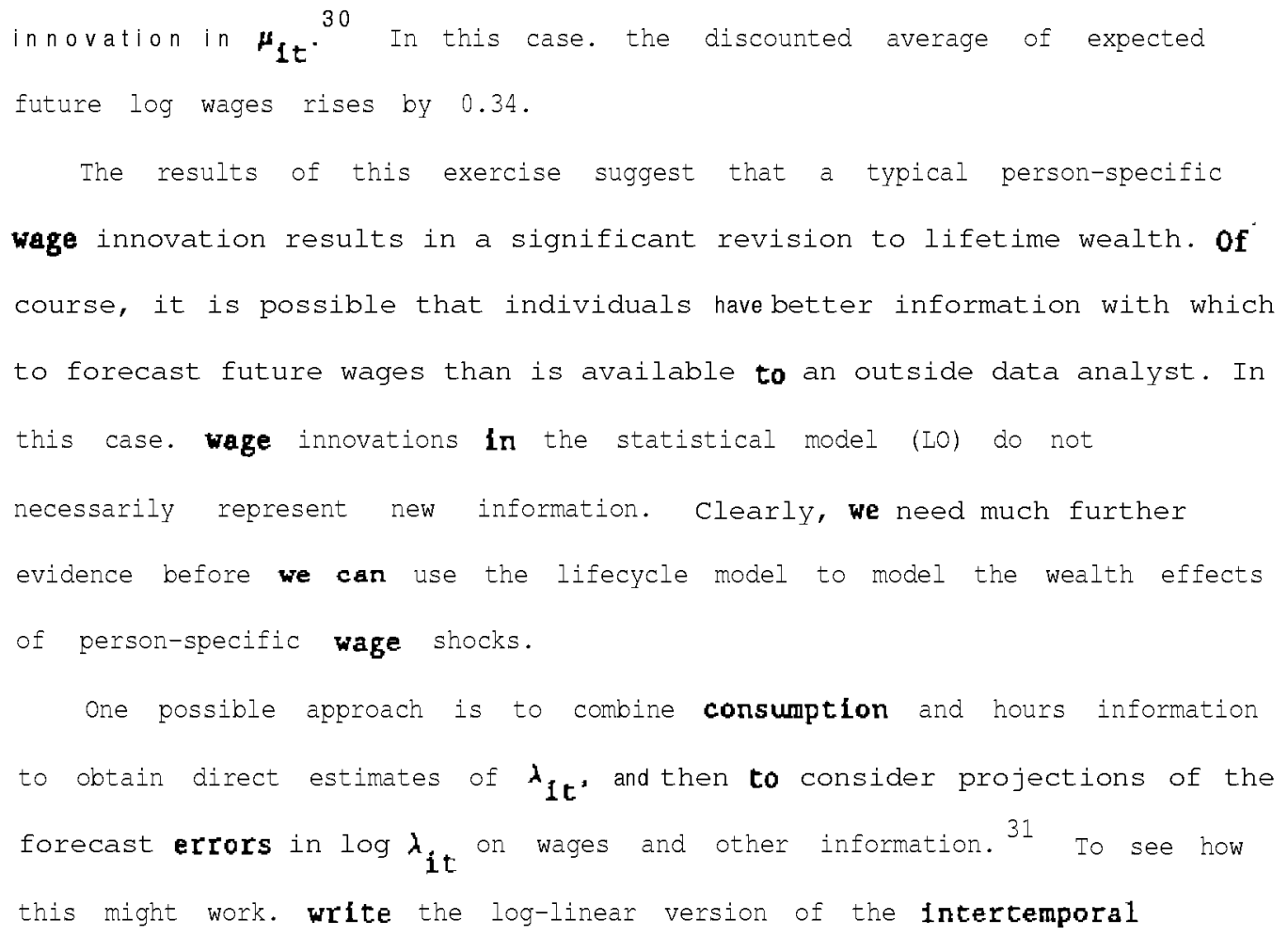




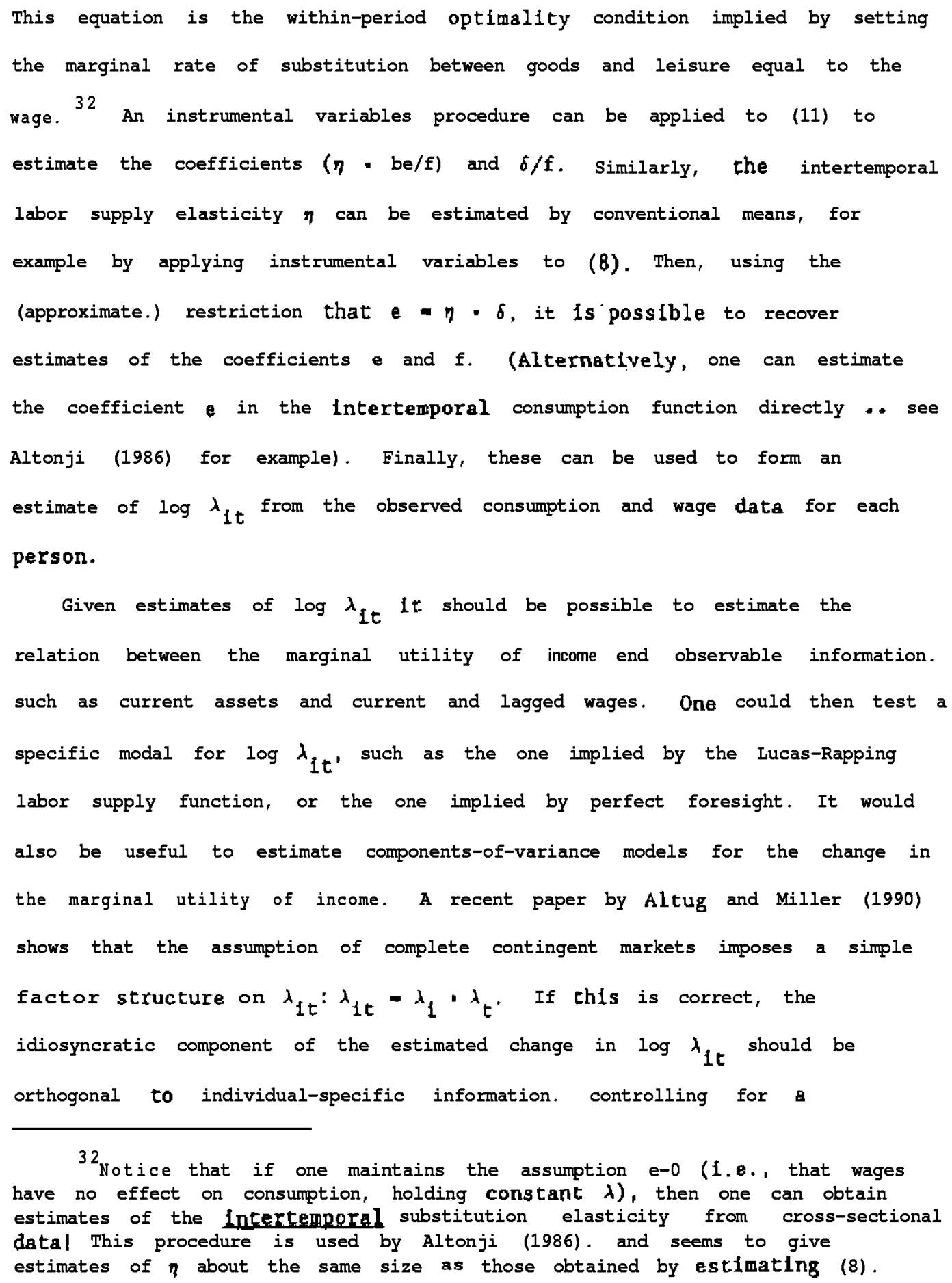


homogeneous time effect. Altug and Miller's results suggest that this set of restrictions may be acceptable.

A major limitation to this line of research is the absence of panel data sets with information $0^{\prime \prime}$ consumption expenditures. The leading panel data source, the PSID, only contains information on food expenditures. Some progress may be possible using the cohort level data in the British Family Expenditure Survey, although the labor supply information contained in this survey is limited to weekly hours.

d. Other Sources of Variation in Individual_Labor_Supply

Although careful $\square$ odelling of wealth effects may go some way toward improving our understanding of the determinants of individual labor supply, I am not optimistic that a conventional lifecycle model can ever explain more than a tiny fraction of the year-to-year variation in the data. 33 one may be tempted to attribute the unexplained changes to tastes or measurement error. There is a graving body of evidence, however, which suggests that idiosyncratic changes in labor supply are systematically related to conditions on the demand side of the labor market. There are two complementary explanations for this link. On one hand, individuals may be unable to sell all their offered labor supply. On the other, some form of fixed costs may enter into either the supply or demand sides of the labor market.

Ashenfelrer and Ham (1979) and Ham (1986) present models of Intertemporal labor supply which assume that reported unemployment contains

33 For example, Altonj's (1986) use of observed food consumption as a control for the marginal utility of income results in only a small increase in the explanatory power of his fitted labor supply equations. 


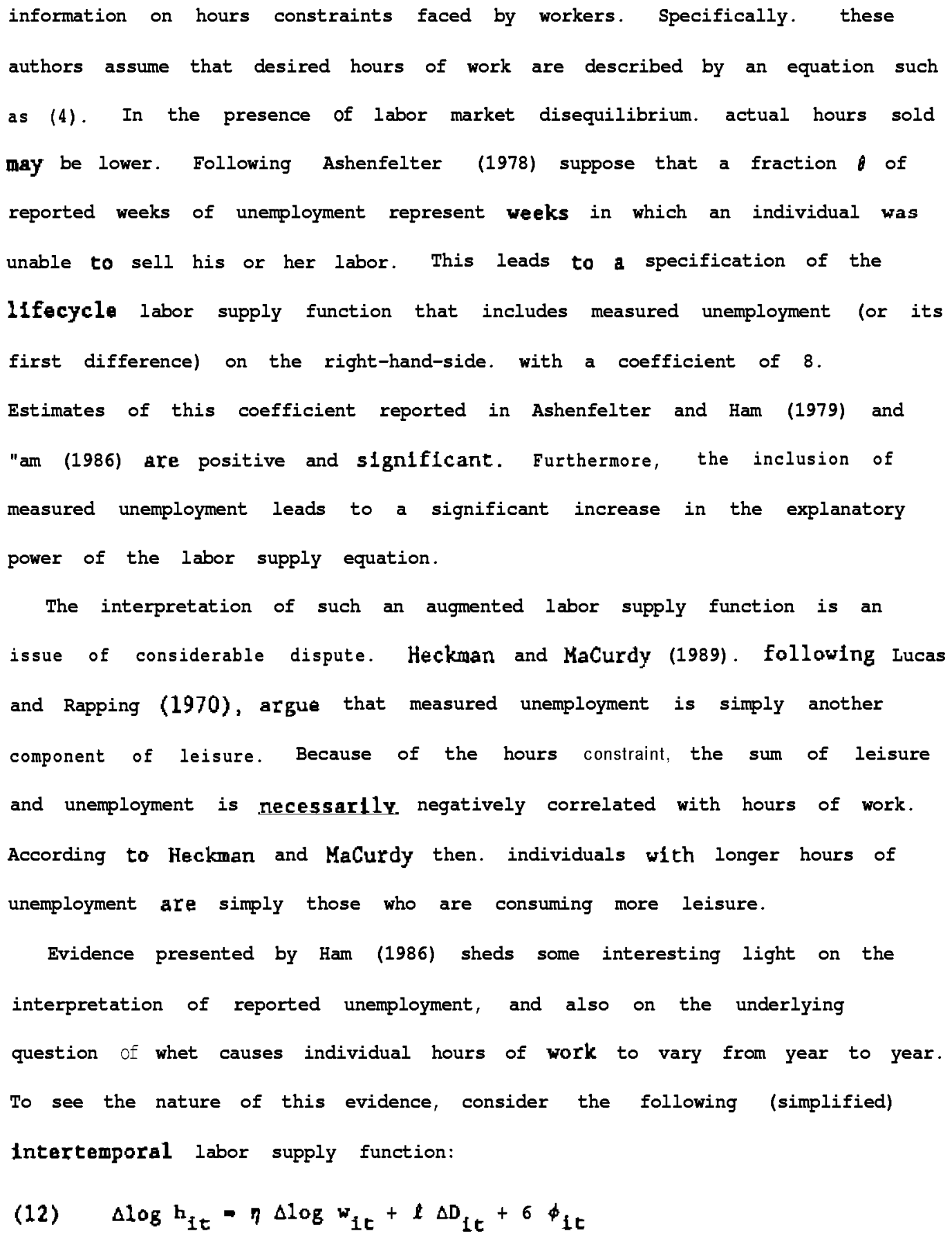

$$
\Delta \log h_{1 t}=\eta \Delta \log w_{1 t}+l \Delta D_{1 t}+6 \phi_{1 t}
$$




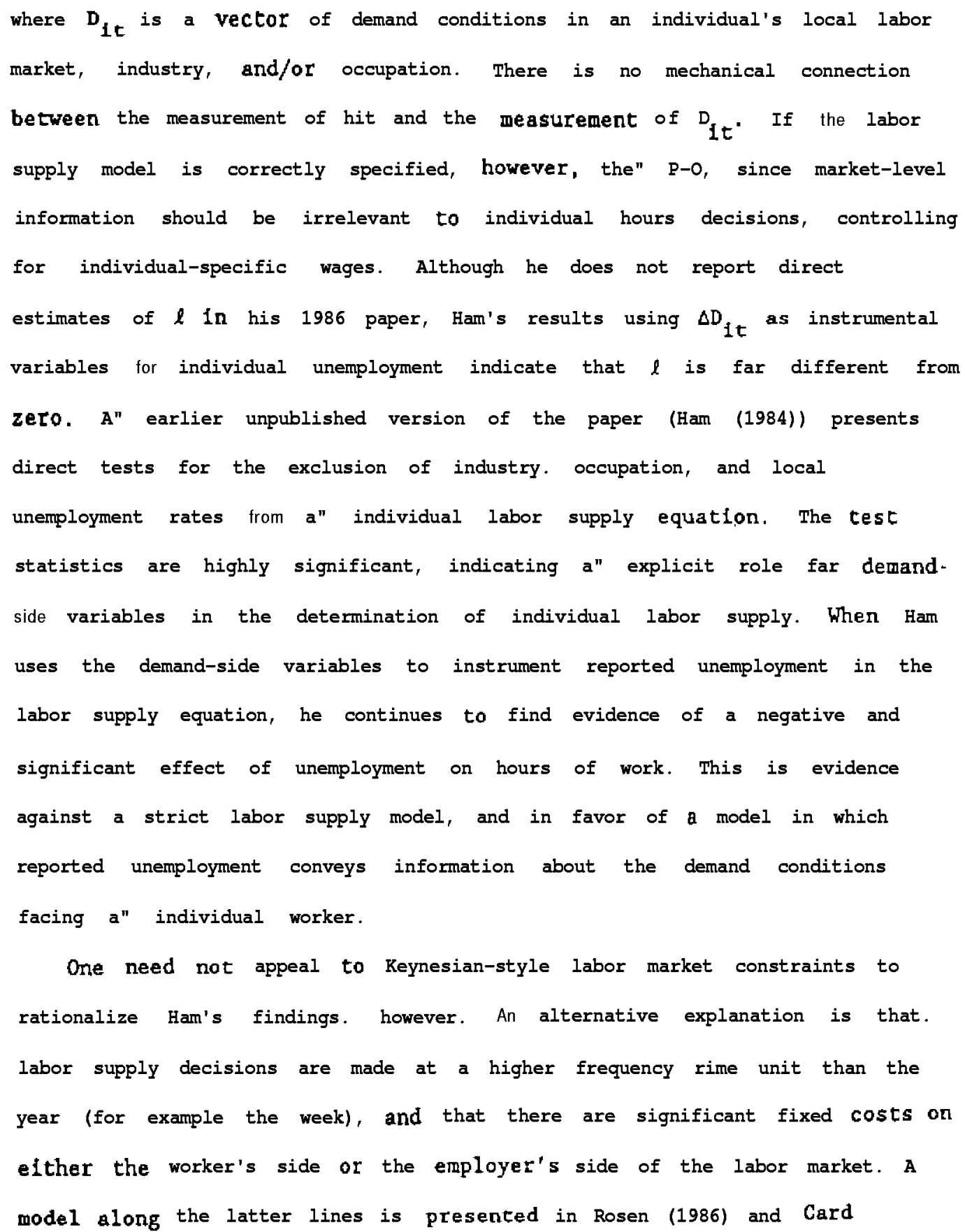


(1990). 34 In this model, effective labor input from a pool of $N$ workers is $\mathrm{Ng}(\mathrm{h})$, where $\mathrm{g}$ is an s-shaped function of hours worked per person. The optimal employment policy of a firm with this technology consists of a two. part rule: if product demand is sufficiently low, lay off a fraction of the labor force and employ the remainder at some minimum threshold level of hours. If product demand is sufficiently high, employ all available workers at hours above the threshold.

The implications of this firm-level behavior for individual labor supply data are two-fold. First. some component of annual hours variation will occur at a fixed hourly wage rate. In particular. individuals working at firms with relatively low product demand will vary their number of weeks worked. but in each week of employment they will supply the same number of hours, and (presumably) earn the same weekly wage. For these individuals. hours of work will vary directly with measures of the firm's product demand. Second, weekly hours will be observed to fluctuate above a (parson-specific) minimum threshold. Evidence presented in Card (1990) indicates that the latter prediction is surprisingly close to the truth. In a sample of 2800 men observed working for the same employer over a two year period. reported hours per week in each of 8 interviews were observed to fall below 35 hours par week in only 11 percent of cases. 35

A simple fixed cost model of this kind suggests that employer demand conditions should affect weeks of employment per year. Predictions on the connection between employer demand and hours per week depend on the assumed

${ }^{34}$ A class of models with similar properties are analyzed in a macro context by Hansen (1985) and Rogerson (1988). In these papers, labor supply within tha week is assumed to be either 0 or 1 .

${ }^{35}$ See Card (1990, Table 3). 
form of employment contract. My paper (Card (1990)) presents a case in which. conditional on working, hours per week lie on a conventional supply schedule. I" this case, controlling for the wage, employer demand should have no effect on hours per week. Some simple evidence on this prediction is presented in Table 3, which shows the results of estimating the augmented labor supply function (12) a" three measures of labor supply: hours per week, weeks per quarter. and total quarterly hours.

The data summarized in Table 3 pertain to me" Ln the 1984 SIPP panel. The sample is restricted to individuals who are observed working for at most one employer over the 9 quarters of the available sample period. Demand-side conditions are measured by the logarithm of employment in the individual's one-dlglt industry. Thus, $\Delta \mathrm{D}_{1 \mathrm{t}}$ refers to the percentage change in employment in an individual's industry in the most recent quarter. The equations are estimated by instrumental variables. using as an instrument for wages the change in wages observed for the same person 4 quarters in the past or 4 quarters in the future. There is a small but highly significant seasonal correlation in individual wage changes that gives this instrumental variable its power.

The estimates suggest that measures of employment demand are significantly correlated with both hours per week and weeks per quarter. I" comparison, the estimated intertemporal substitution elasticities are small and relatively imprecise. ${ }^{36}$ one could easily conclude from this evidence that changes in labor supply are directly connected to employer

\footnotetext{
${ }^{36}$ OLS estimates of the equation result in negative and significant wage coefficients. presumably as a consequence of measurement error in average hourly earnings. Further results are reported in Card (1990).
} 
demand conditions, and that wages play little or no role in the short-run labor-leisure decision.

The relatively weak connection between hours per week and wages illustrated in columns 1 and 4 of Table 3 may seem puzzling. give" that the Fair Labor Standards Act mandates overtlme payments for individuals in many occupations who work over 40 hours per week. Some additional evidence $0 "$ the relation between weekly hours and wages is provided by data in the May 1985 CPS, This survey gathered information on usual hours per week, actual hours worked in the previous week, and whether or not the individual received any overtime payments. The responses suggest that there is substantlal variation in actual weekly hours around "usual" weekly hours: 13 percent of me" indicate that they worked lass than their usual hours. while another 19 percent indicate that they worked more. ${ }^{37}$ Individuals in the letter group report 10 extra hours per week on average, bringing their weekly total to 51 hours. However, only 47 percent of these men report receiving any additlonal overtime compensation. For the majority. weekly hours are higher then ugual but weekly earnings are fixed. 38

Table 4 provides more detailed information on a very narrow subset of Individuals .. those who usually work $35-40$ hours per week and who report 41 or more hours in the survey week. ${ }^{39}$ sixty-two percent of all workers normally work 35-40 hours per week. Of these, 13.5 percent worked 41 or

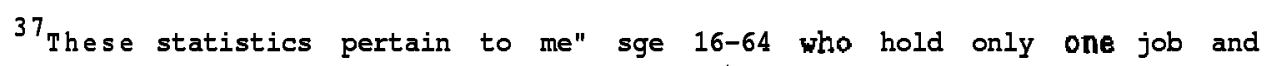
who are not self-employed. Variation in weekly. hours among the excluded group is even larger.

${ }^{38}$ Unfortunately, the survey does not ask about reduced compensation for individuals who worked less than usual hours.

${ }^{39}$ In s" effort to obtain a reasonably large sample, this table includes both ma" and women. 
more hours In the survey week, and are summarized in the Table. The fraction receiving overtime compensation among this group is 59 percent. Interestingly. however, extra hours worked are actually slightly higher for the group with no overtime pay.

These data suggest that even within the week, simple labor supply model Is inadequate for a large fraction of the population. Many individuals appear to be working extra hours for no extra pay. "he" this behavior is added to the phenomenon of weekly layoffs, it becomes clear how a simple model of labor supply can easily fail to explain movements in annual hours.

Further work is obviously needed to isolate the systematic components

of individual labor supply, and to describe the links between employer demand and employee hours choices. While such work falls outside the "arrow realm of a conventional Iffecycle model. it seems to me that further understanding of individual hours outcomes will require a broader perspective than the standard model can provide. As it stands. the lifecycle model provides essentially no insight into the year-to-year variation in individual hours.

\section{IV, Conclusions}

I" principle. the lifecycle labor supply model offers a" explanation for the four main aspects of individual hours choices: mea" hours over the lifecycle; the age profile of hours; aggregate movements in hours; and individual-specific variation in hours around the lifecycle profile. All of these components are tied together by a combination of Intertemporal substitution effects and wealth effect. In this paper I have tried to 


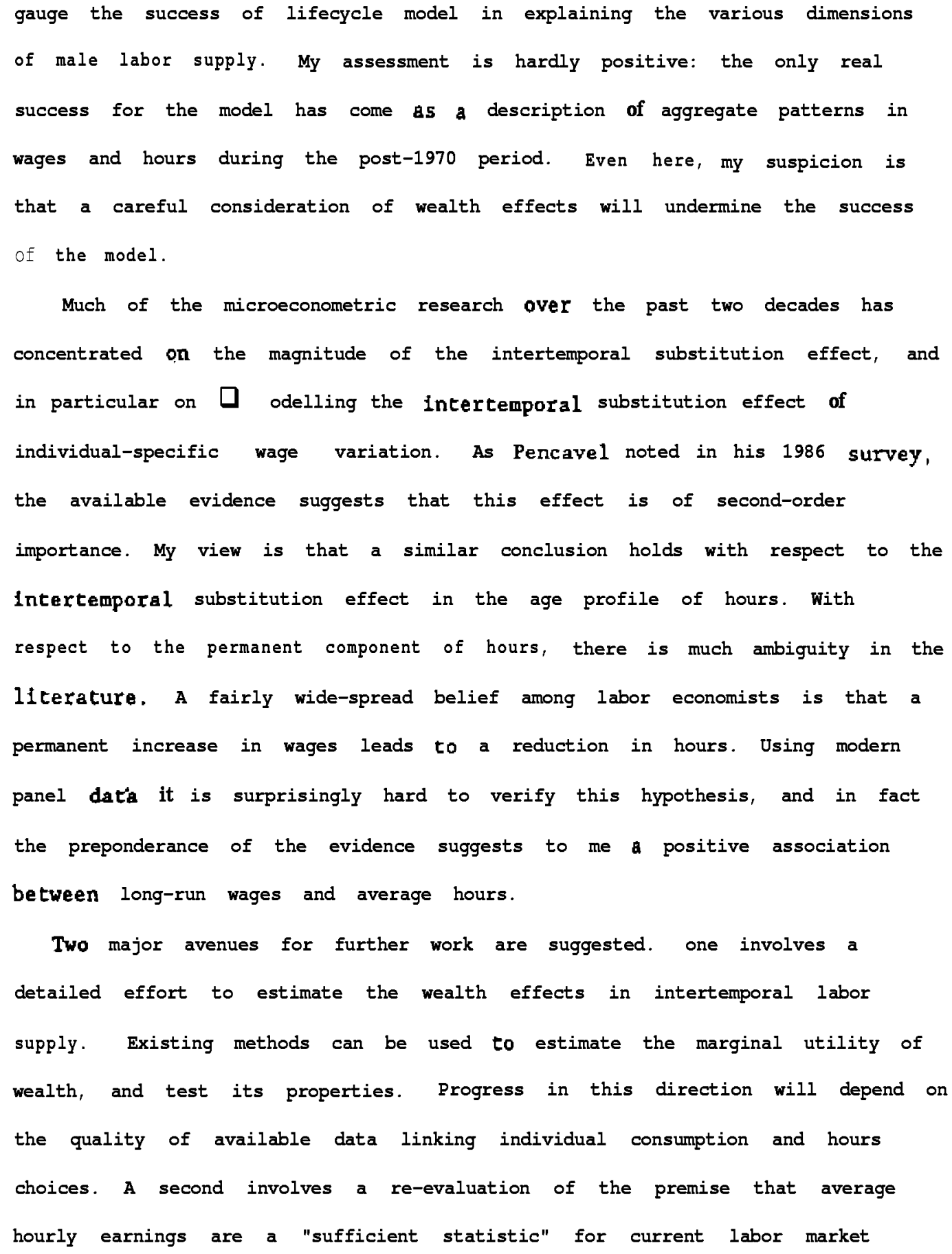


opportunities. A variety of models suggests that individual hours are

influenced directly by employer-specific demand conditions. Iimited

empirical evidence confirms this suspicion. If true, our basic notions of

labor supply, and in particular our notions about the degree of

substitutability between current and future leisure. may be incomplete. 
Altonj 1, Joseph G. "The Intertemporal Substitution Model of Labor Market Fluctuations: An Empirical Analysis." Revlew of Economic Studies. 49 (Supplement, 1982): 783-824.

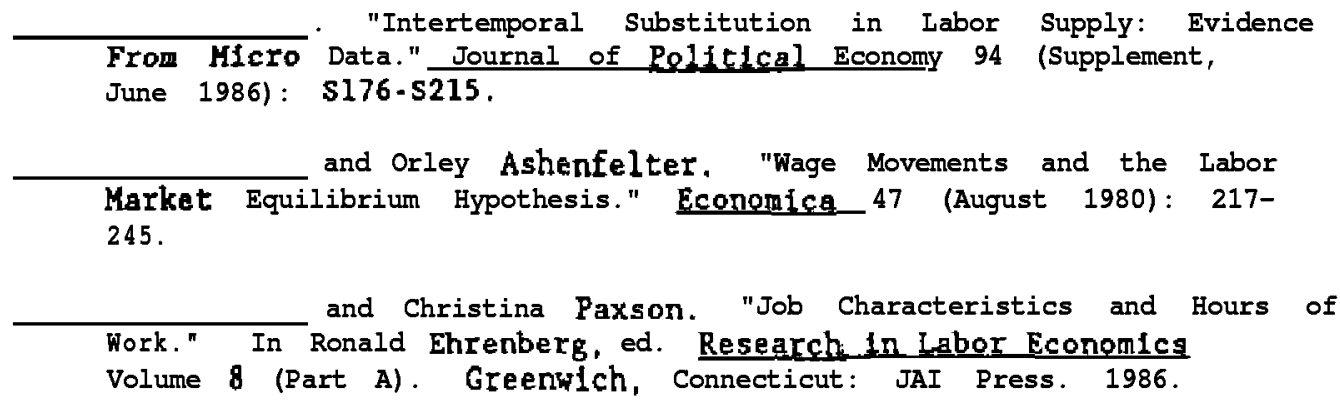

Altug. Sumru and Robert A. Miller. "Household Choices in Equilibrium." Econometrica 58 (May 1990): 543-570.

Angrist, Joshua D. "Grouped Data Estimation and Testing in simple Labor Supply Models." Unpublished Manuscript. Cambridge MA: Department of Economics, Harvard University, April 1989. Fortheoming in Journal of Econometrics 45 (1990). "Does Labor Supply Explain Fluctuations in Average Hours Worked?' DLscussion Paper 1476. Cambridge MA: Department of Economics, Harvard University, March 1990.

Ashenfelter, Orley. 'Unemployment as a Constraint on Labour Market Behavior: In M. Artls, ad. Proceedings of the 1977 Meeting of fhe Association of University Teachers of Economics. Oxford: Basil Blackwe11, 1978.

Microecononic Analyses and Macroeconomic Analyses of Labor Supply. In K. Brunner and A. Meltzer, eds. CarnegieRochester Conference Series on Public Policy 21. Amsterdam: North Holland, 1984 . and John Han. "Education, Unemployment and Earnings." Journal of Political Economy 87 (supplement, December 1979): S99S116.

Blunde11, Richard. "Evaluating Structural Microeconometric Models of Labour Supply.' Unpublished Manuscript. London: Department of Economics, University College, July 1990.

Bound, John, Charles Brown. Greg J. Duncan and Willard L. Rogers. - Measurement Error in Cross-Sectional and Longitudinal Labor Market Surveys: Results from Two Validation Studies." NBER Working Paper Number 2884. Cambridge MA: National Bureau of Economic Research. March 1989. 
Browlng, Martin, Angus Deaton and Margaret Irish. "A Profitable Approach to Labor Supply and Commodity Demands Over the LifeCycle." Econopetrlca_53 (May 1985): 503-543.

Card, David. "Labor Supply with a Minimum Hours Threshold". Princeton University Industrial Relations Section Working Paper Number 262, Princeton New Jersey: Industrial Relations Section. February 1990. Forthcoming in A. Meltzer, ed. Carnegle Rochester Conference on Public Policy 33. Amsterdam: North Holland, 1990.

Carrol, Cbis and Lawrence H. Summers. "Consumption Growth Parallels Income Growth: Some New Evidence." Unpublished Working Paper. Cambridge MA: Department of Economics, Harvard University. 1989.

Duncan, Greg J, and Dan H. Hill. "An Investigation into the Extent and Consequences of Measurement Error in Labor-economic Survey Data." Journal of Labor Economics 3 (1985): 508 -532.

Finegan, T. Aldrich. "Hours of work in the United Stares: A CrossSectional Analysis." Journal of Political Economy 70 (October 1962): $452-470$.

Eriedman, Milton. Prlce Theory. Chicago: Aldine Publishing Co.. 1976.

Ghez, Gilbert and Gary S. Becker. Mllecation of Time and Goods over the Tefeycdek. Columbia University Press, 1975.

Ham, John. "Testing Whether Unemployment Represents Intertemporal Labor Supply Behavior." Unpublished Manuscript Presented at University of Manchester, July 1984.

- "Testing whether Unemployment Represents Intertemporal Labor Supply Behavior." Review of Fconomic Studies 53 (1986): 559-578.

Hansen, Gary. "Indivisible Labor and the Business Cycle." Journal of Monetary Economics 16 (November 1985): $309-327$.

Heckman, James J. "Life Cycle Consumption and Labor Supply: A" Explanation of the Relationship Between Income and Consumption Over the Life Cycle." Amerlcan Economic Review 64 (March 1974): 188-194.

-A Iife-Cycle Model of Earnings, Learning, and Consumption." Journal of Policical Economy a 4 (Supplement, August 1976): Sil-S44.

Equilibrium: A" Evaluation." In K. Brumer and A. Meltzer, eds. Carnegle-Rochester Conference Series on Public Pollcy 28. Amsterdam: North Holland, 1988. 
Holz-Eakin, Douglas, Whitney Newey and Harvey S. Rosen. 'Estimating Vector Autoregressions with Panel Date" Econometrlca 56

(November 1988): 1371-1395.

Killingsworth, Mark R. Labor Supply. Cambridge: Cambridge University Press, 1983.

Lewis. H. Gregg. "Hours of Work and Hours of Leisure". In L. Reed Tripp, ed. Broceedings of the Ninth Annual Meeting of the Industral Relations Research Assoclation. Madison Wisconsin: IRRA， 1956.

Lucas, Robert E. and Leonard Rapping. "Real Wages, Employment and Inflation". In E. S. Phelps, ed. Meroecsonofic Foundations of Employment and Inflation Theory. New York: Norton, 1970.

MaCurdy, Thomas E. "A" Empirical Model of Labor Supply in a Iife-Cycle Setting." Journal of Political Economy 89 (December 1981):10591085 .

- "A Simple Scheme for Estimating a" Intertemporal Model of labor Supply and Consumption in the Presence of Taxes and Uncertainty." International Economic Review 24 (June 1983): 265-289.

- "Interpreting Empirical Models of Labor Supply in a" Intertemporal Framework with Uncertainty." In J. J. Heckman and. B. Singer, eds. Longltudinal Analys is of Labor Market Rata. Cambridge: Cambridge University Press, 1985.

Mankiw, N. Gregory, Julio J. Roremberg and Lawrence H. Summers. "Intertemporal Substitution in Macroeconomics." Ouarterly Journal of Economics 100 (February 1985): X5-251.

Mincer. Jacob. "Labor Force Participation of Marrled Women: AStudy of Labor Supply.. In National Bureau of Economic Research, Aspects or lbor Economlcs. Princeton N.J.: Princeton University Press, 1962 .

Pencavel, John "Labor Supply of Men: A Survey." In 0 . Ashenfelter and R. Layard, eds. Handbook of Labor Economics. Amsterdam: North Holland, 1986.

Rogerson, Richard. "Indivisible Labor, Lotteries, and Equilibrium." Jounal of MonetaryEconomlcs 21 (July 1988): 3-16.

Rosen, Sherwin. "Implicit Contracts: A Survey." Journal of Economic Literature 23 (1985): 1144-1176.

Thurow, Lester $c$. "The optimum Lifetime Distribution of Consumption Expenditures." Amerlcan Economic Review 59 (June 1969): $\mathbf{3 2 4 - 3 3 0 .}$ 
Iabl* 1

Auta-coveriance Structure of Indlvidual Hagea

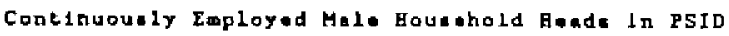

$1072-78$

(etcimated atanderd arrora in parontheses)

Auto-covarlance of Hase in:

\begin{tabular}{|c|c|c|c|c|c|c|c|c|}
\hline & \multicolumn{8}{|c|}{ Auto-covarlance of Wase in: } \\
\hline & 1971 & 1872 & 1973 & 1974 & 1975 & 1976 & 1877 & 1978 \\
\hline \multicolumn{9}{|c|}{ Hith Wase in: } \\
\hline \multirow[t]{2}{*}{1971} & 0.243 & & & . & & & & \\
\hline & $(0.012)$ & & & & & & & \\
\hline \multirow[t]{2}{*}{1972} & 0.186 & 0.252 & & & & & & \\
\hline & $(0.010)$ & $(0.021)$ & & & & & & \\
\hline \multirow[t]{2}{*}{1973} & 0.185 & 0.190 & 0.251 & & & & & \\
\hline & $(0.010)$ & $(0.011)$ & $(0,012)$ & & & & & \\
\hline \multirow[t]{2}{*}{1974} & 0.180 & 0.188 & 0.194 & 0,240 & & & & \\
\hline & $(0.010)$ & $(0.010)$ & $(0.020)$ & $(0.012)$ & & & & \\
\hline \multirow[t]{2}{*}{1975} & 0.173 & 0.187 & 0.187 & 0.193 & 0.253 & & & \\
\hline & $(0.010)$ & $(0.020)$ & $(0.010)$ & $(0.010)$ & $(0.011)$ & & & \\
\hline \multirow[t]{2}{*}{2976} & 0.168 & $0.17 \theta$ & 0.180 & 0.188 & 0.206 & 0.271 & & \\
\hline & $(0.010)$ & $(0.010)$ & $(0.010)$ & $(0.010)$ & $(0.010)$ & $(0.012)$ & & \\
\hline \multirow[t]{2}{*}{1977} & 0.163 & 0.177 & 0.180 & 0.183 & 0.165 & 0.205 & 0.254 & \\
\hline & $(0.010)$ & $(0.010)$ & $\{0,010\}$ & $(0.010)$ & $(0.010)$ & $(0.010)$ & $(0.011)$ & \\
\hline \multirow[t]{2}{*}{1878} & 0.151 & 0.166 & 0.164 & 0.170 & 0.180 & 0.185 & 0.205 & 0.293 \\
\hline & $(0.010)$ & $(0.010)$ & $(0.010)$ & $(0.010)$ & $(0.010)$ & $(0.011)$ & $(0.011)$ & $(0.016)$ \\
\hline \multirow[t]{4}{*}{ Ayere } & - Auto-co & rartanca & et Las: & & & & & \\
\hline & 7 & 6 & 5 & 4 & 3 & 2 & 1 & 0 \\
\hline & 0.151 & 0.165 & 0.169 & 0.175 & 0.182 & 0.18 .8 & 0.200 & 0.257 \\
\hline & $(0.010)$ & $(0.000)$ & $(0.009)$ & $(0.009)$ & $(0.009)$ & $(0.000)$ & $(0.000)$ & $(0.008)$ \\
\hline
\end{tabular}

Hote; Semple conciste of 1374 mal hausbold hende from houtholds with no chenge In head betweon 1969 and 1879, who warned poiftive labor earingt

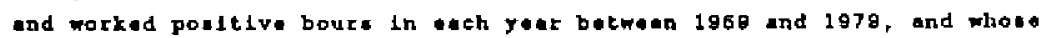
hourly wage was botwoon 50.75 and 3100 (1n conetant 1967 dollora) in all yaxa, 

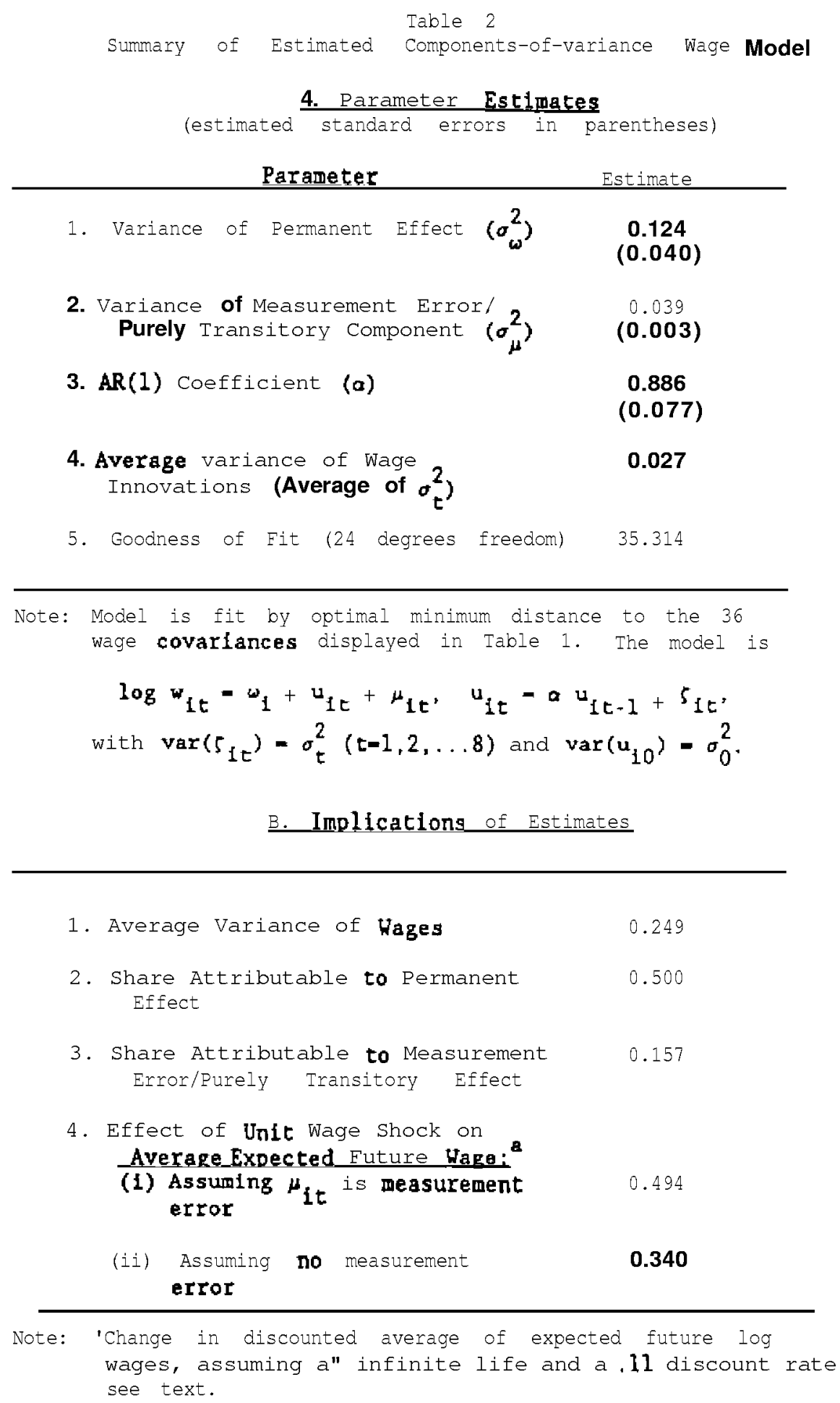
Estimated Labor Supply Functions for

Quarterly Hours Outcomes: SIPP Sample of Hen

$$
\text { (standard errors in parentheses) }
$$

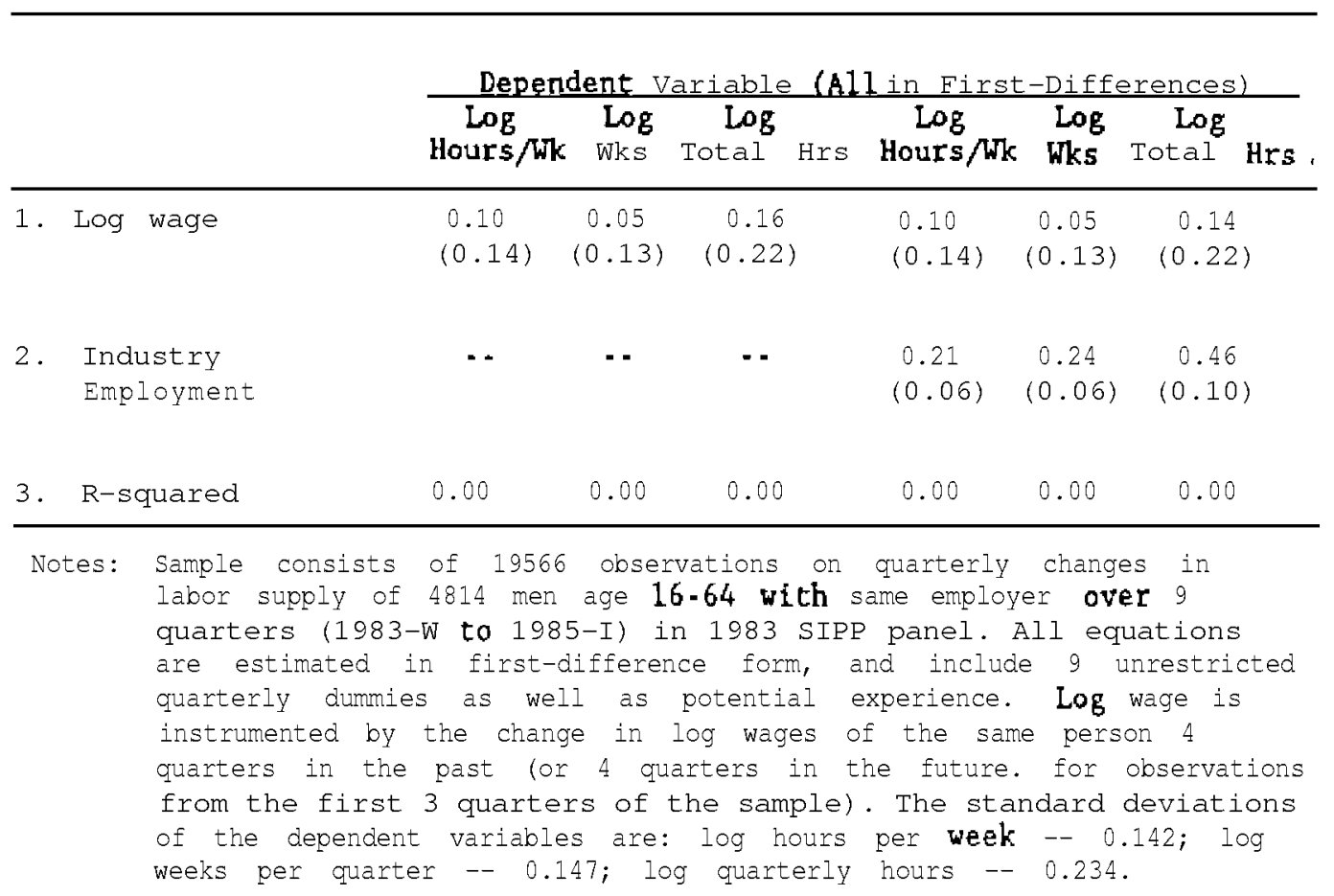




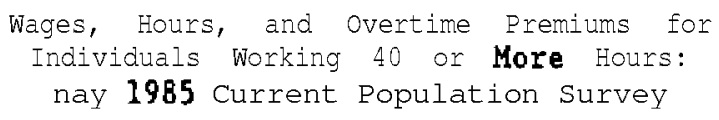

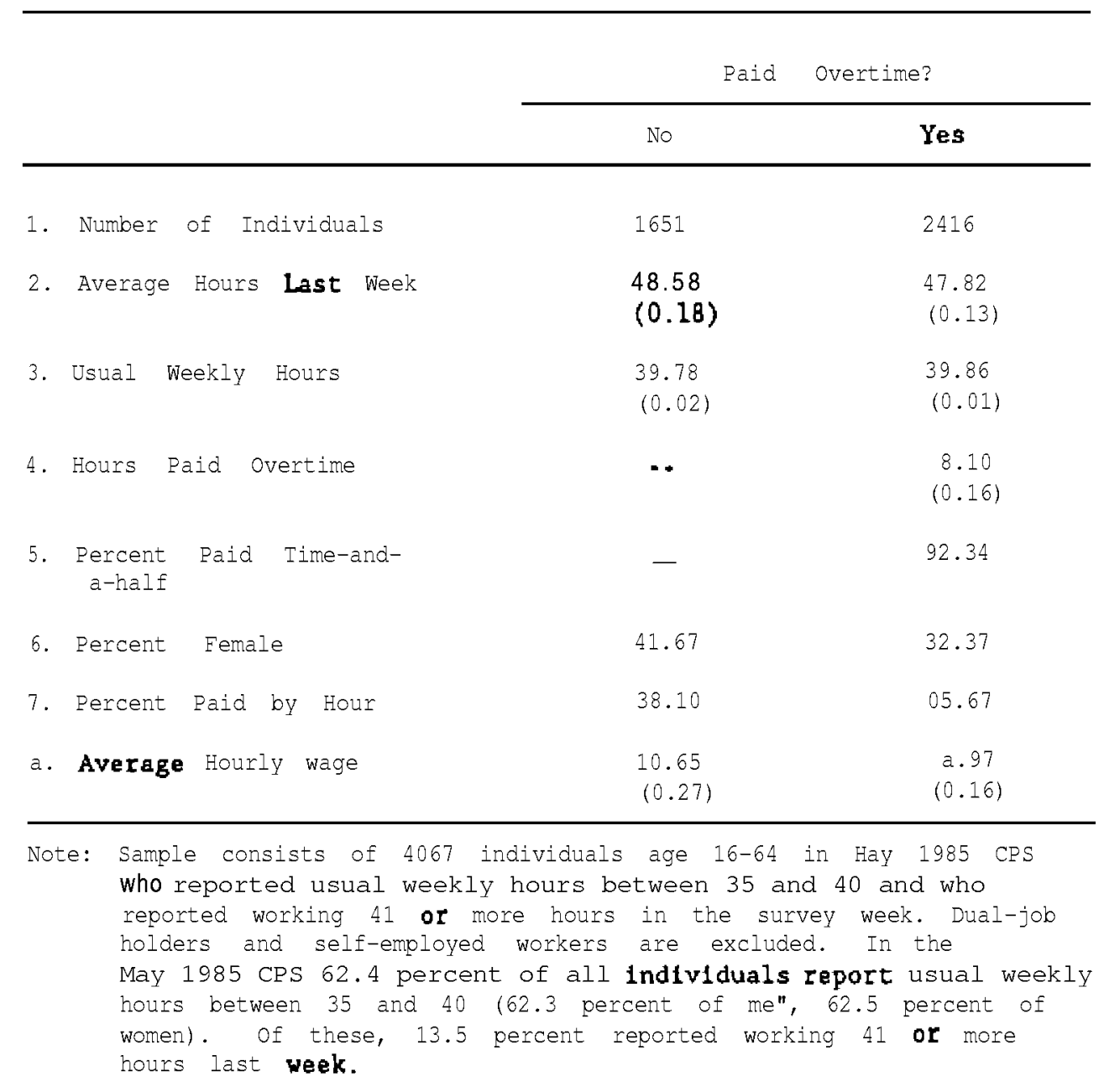




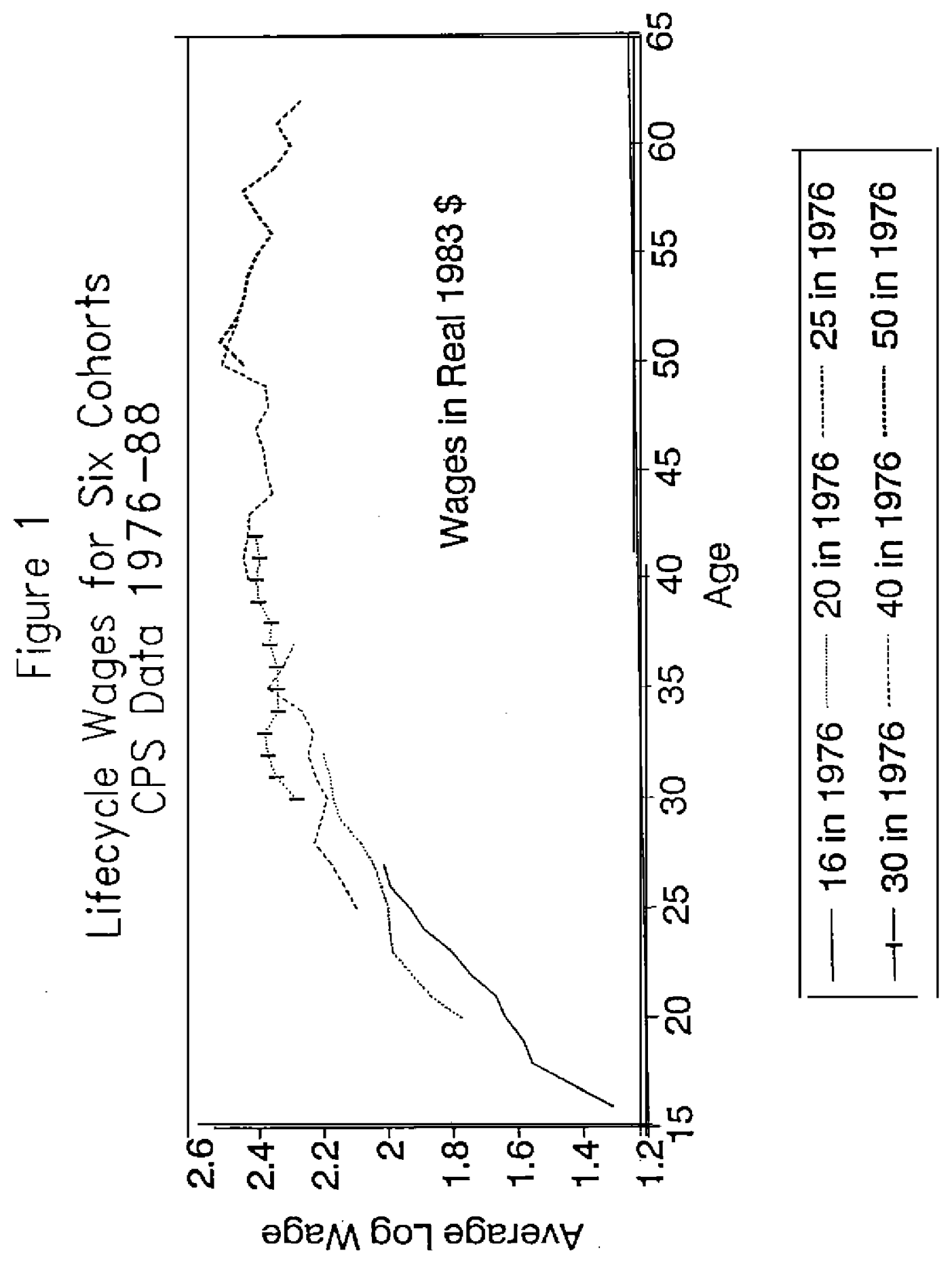


Figure 2

Lifecycle Hours for Six Cohorts

CPS Data 1976-88

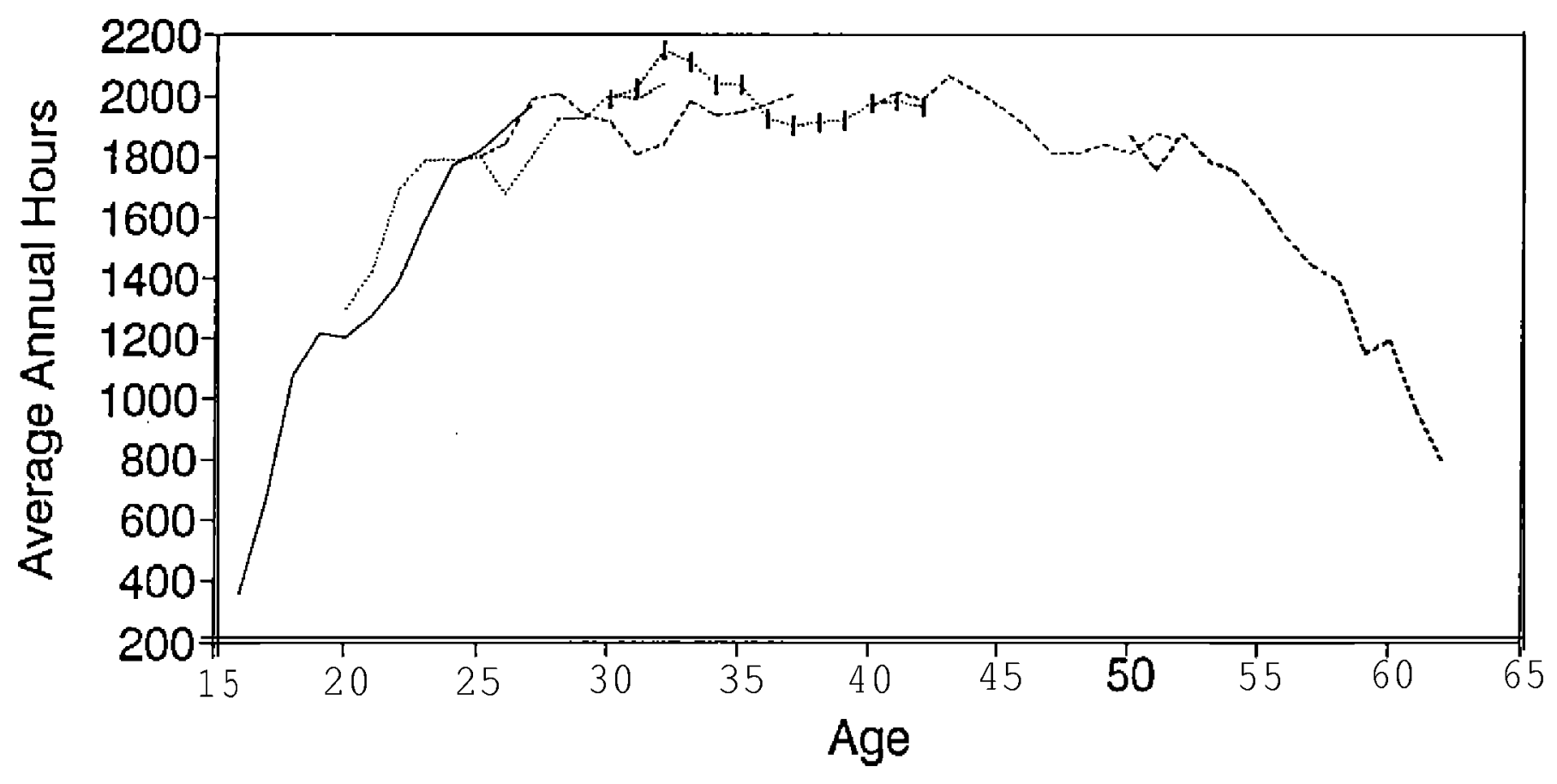

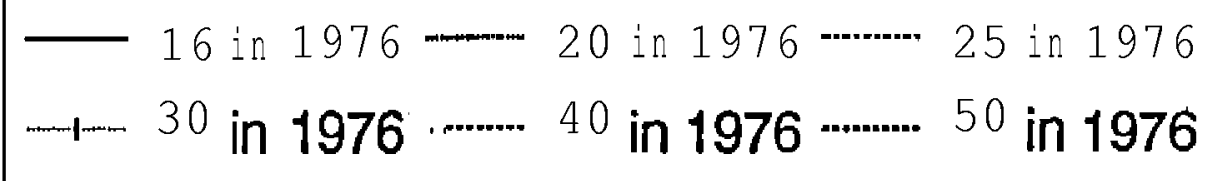




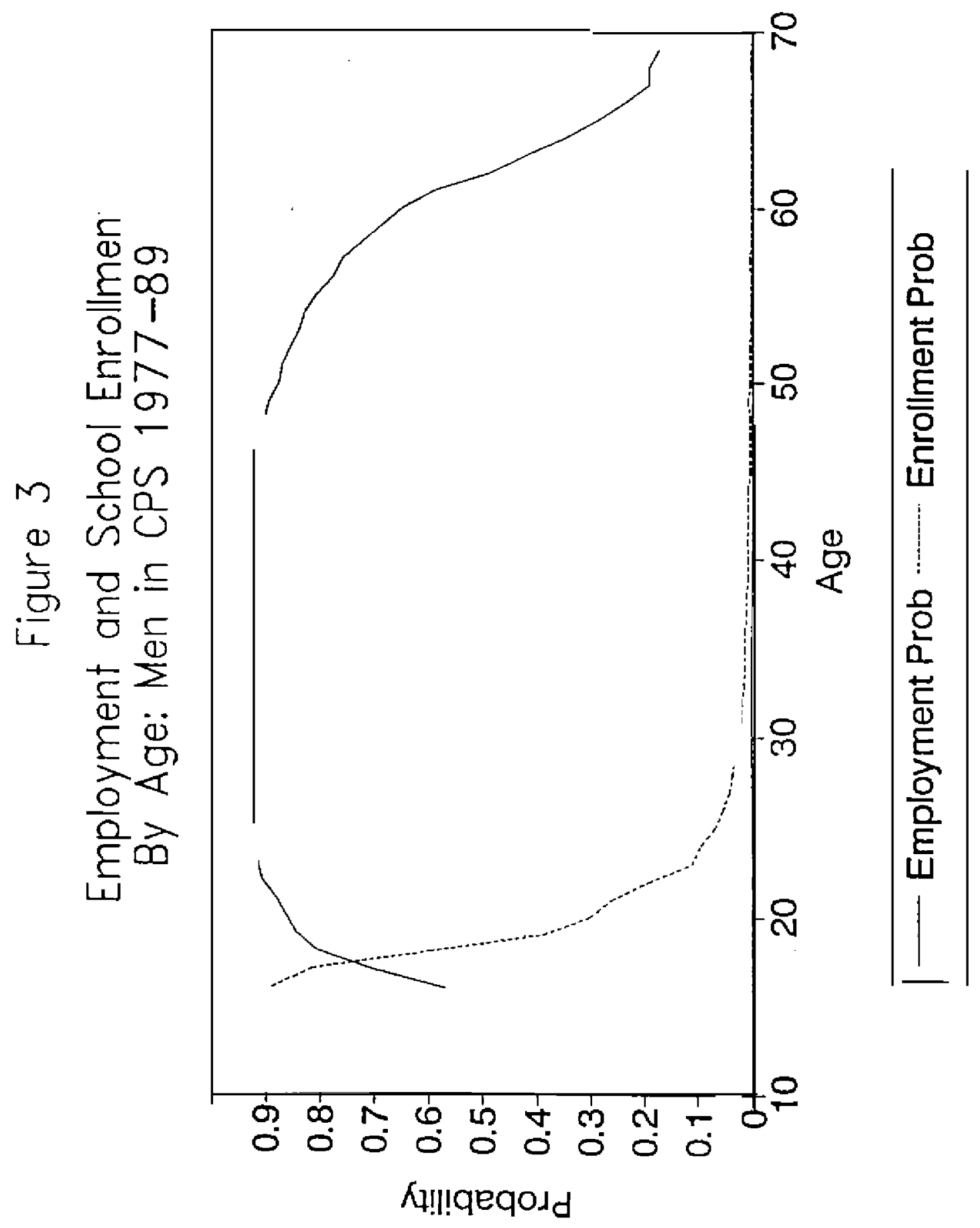


Figure 4

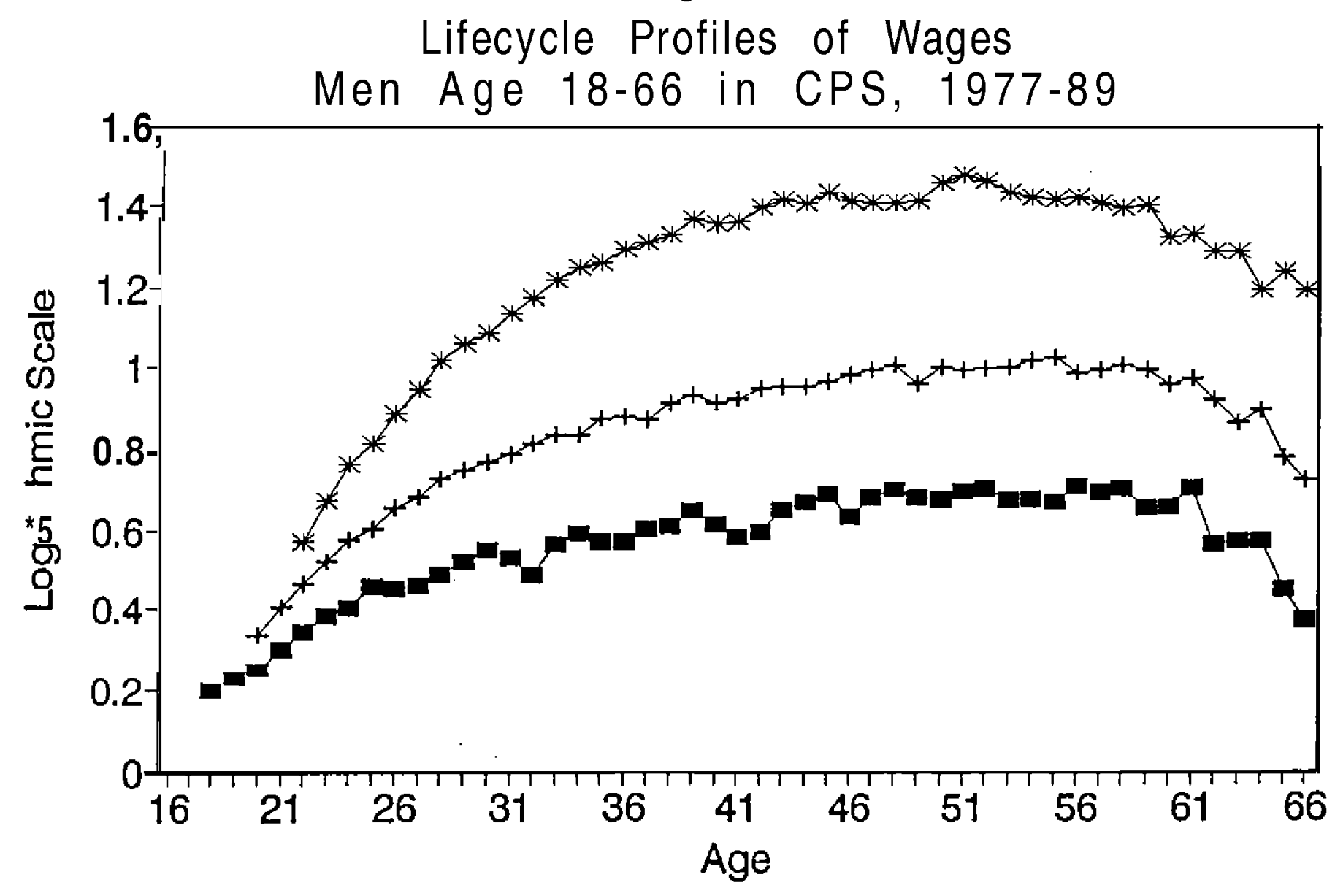

$\rightarrow$ 0-8 Years Educ $\rightarrow 12$ Years Educ $* 16+$ Years Educ 
Figure 5

Lifecycle Profiles of Hours

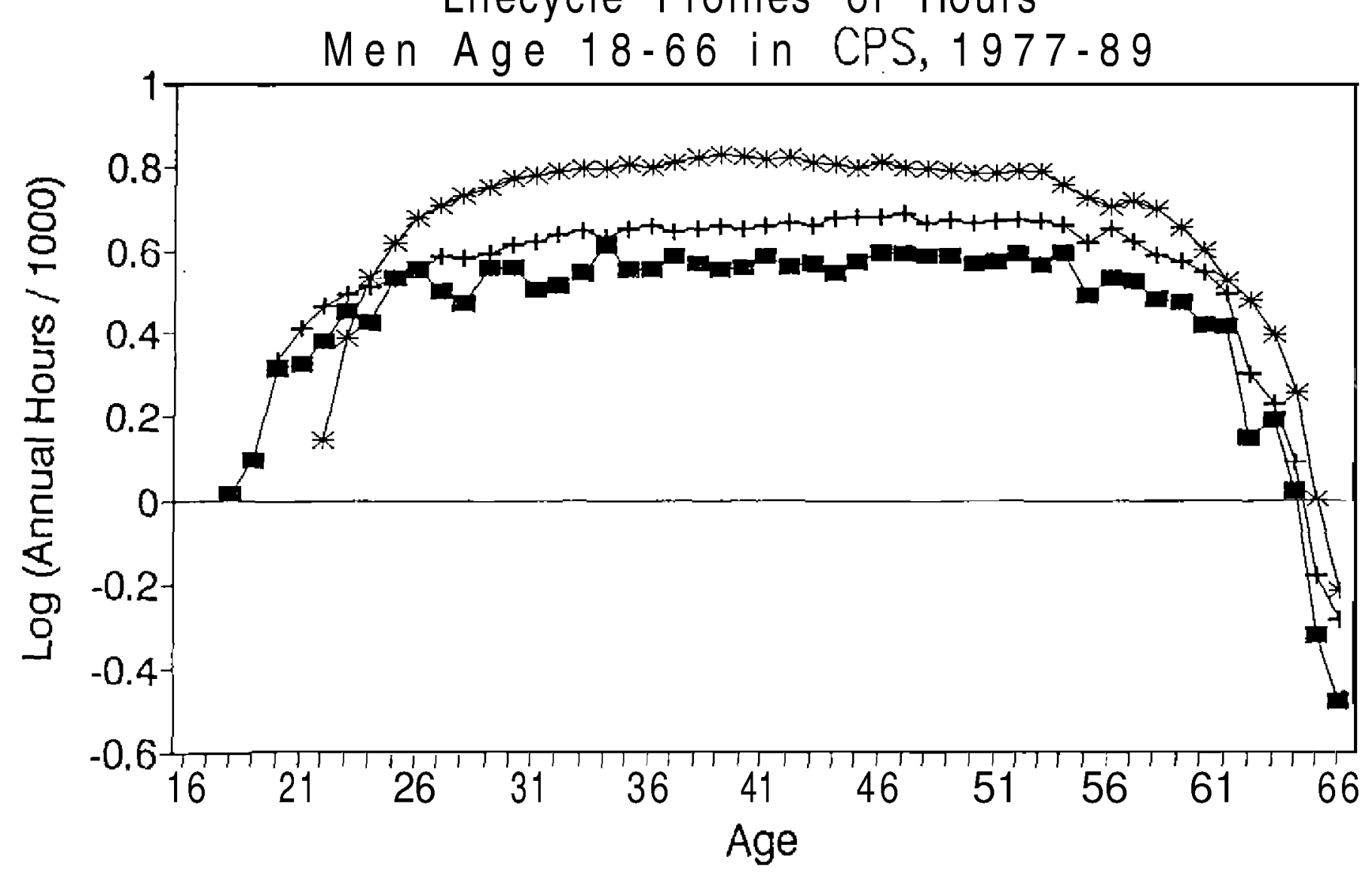

$\rightarrow-0-8$ Years Educ $\rightarrow 12$ Years Educ $\rightarrow-16+$ Years Educ 


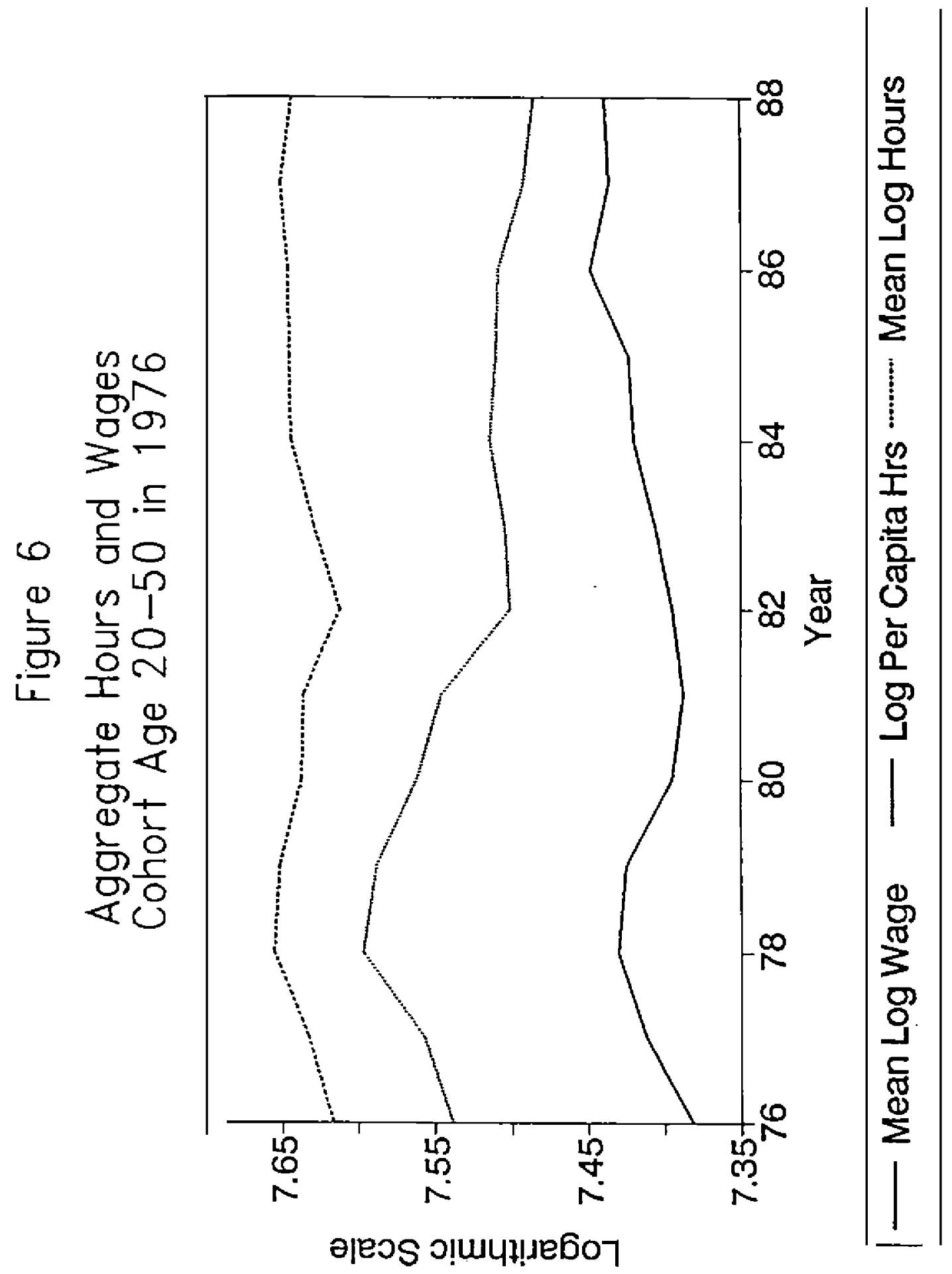


Number Author

3542 Sherwin Rosen

3543 Rabert P. Flood Andrew $K$. Rose

Donald J. Mathieson

3544 Anne 0 . Krueger

3545 Anne 0. Krueger David orsmond

3546

Steven F. Venti David A. Wise

$3548 \quad$ Patric Hendershott

3549 Theodore Joyce

3550 Frederic S. Mishkin

3551 Gary Gorton George Pennacchi

3552 Pussell Cooper Jahn Haltiwanger

3553 s. Iael Brainard

3554 A 1 - Casella Jonathan S. Feinstein

3555 Laurence Ball

3556 Craig Eurnside Martin Eichenbaum Sergio Rebelo

3557 Jonathan Gruber Alan B. Krueger
Title

Date

Contracts and the Market for Executives $12 / 90$

An Empirical Exploration of Exchange $12 / 90$

Rate Target-zones

The Political Econonty of American

$12 / 90$

Protection in Theory and in Practice

$12 / 90$

Impact of Govermment on Growth and

'Trade

'Liquidation' Cycles: Old-Fashioned

Real Business Cycle Theory and the

Great Depression

Aging and the Inome Value of Housing Wealth

The Market for Home Mortgage Credit: Recent Changes and Future Prospects

$12 / 90$

Self-Selection, Prenatal Care, and

$12 / 90$

Birthweight Anong Blacks, Whites, and

Hispanics in New York City

Yield Curve

$12 / 90$

Banks and Ioan Sales: Marketing Non-

Marketable Assets

$12 / 90$

The Aggregate Implications of Machine

$12 / 90$

Replacement: Theory and Practice

Last one out Wins: Trade Policy in an $12 / 90$

International Exit Game

Public Goods in Trade: on the Formation 12/90

of Markets and political Jurisdictions

Credible Disinflation with Staggered $12 / 90$

Price Setting

Labor Hoarding and the Business Cycle $12 / 90$

The Incidence of Mandated Employer- $\quad 12 / 90$ Provided Insurance: Lessons From Workers' Compensation Insurance 


\section{Number Author}

3558 Robin L. Lumsdaine James H. Stock

David A. Wise

3559 Lawrence H. Goulder Philippe Thalmann

3560 Steven Shavell

3561 Joshua Aizerman

3562 Michael D. Bordo

Anna J. Schwartz

3563 Xavier Sala-i-Martin

3564 Xavier Sala-i-Martin

3565 Cing-to Albert Ma Andrew Weiss

3566 Alan C. Stockman Ininda L. Tesar

3567 Paul J. Gertler Donald M. Waldman

3568 Sanghamita Das

3569 Anne O. Krueger

3570 Giancarlo Corsetti Vittorio Gilli Nauriel Roubini

3571 Joshua D. Angrist Alan B. Krueger

\section{Title}

Date

Three Models of Retirement: Computa$12 / 90$ tional complexity Versus Predictive Validity

Aprroaches to Efficient Capital

$12 / 90$

Taxation: Leveling the Playing Field

vs. Living by the Golden falle

Individual Precautions to Prevent Theft: Private Versus Socially optimal Behavior

Soft Budget Constraints, Taxes, and $12 / 90$ the Incentive to cooperate

What Has Foreign Exchange Market

$12 / 90$

Intervention Since the Plaza Agreement Acoompl ished?

Lecture Notes on Economic Growth (I): $12 / 90$ Introduction to the Literature and Neoclassical Models

Lecture Notes on Economic Growth (II) : 12/90 Five Prototype Models of Endogenous Growth

A Signaling Theory of Unemployment $\quad 12 / 90$

Tastes and Technology in a Two-cauntry 12/90 Model of the Business Cycle: Bplaining

International Comovements

Quality Adjusted Cast Functions $\quad 12 / 90$

A Micro Econometric Model of Capital $12 / 90$ Utilization and Retirement

Theory and Practice of Commercial $12 / 90$ Policy: 1945-1990

Exchange Rate Volatility in Integrating 12/90 Capital Markets

The Effect of Age at School Entry on Educational Attainment: an Application $12 / 90$ of Instrurental variables with Moments from Two samples 
3572 Joshua D. Angrist Alan B. Krueger

3573 Pobert J. IaLonde Robert H. Topel

3574 Fhileqpe Jorion Frederic Mishkin

3575 Ceorge Borjas

3576 Giuseppe Bertola Lars E.0. Svensson

3577 Alwyn Young

3578 James M. Poterba

3579 Barry Eichengreen

3560 Joseph E. Stiglitz

3581 Jacob Mincer

3582 Catherine J. Morrison Enst R. Berndt

3583 Karen K. Lewis

3584 Jeffrey I. Bernstein Pierne Mohnen

3585 Eliana Cardoso

$3586 \quad$ Miles s. Kimball

3587 James B. Rebitzer Michael D. Robinson

3588 Richard Arnott Joseph Stiglitz
Does carpulsory school Attendance Affect schooling and Eamings?

$12 / 90$

The Assimilation of Irmigrants in the $12 / 90$ U.S. Iabor Market

A Multi-Country Conparison of Term Structure Forecasts at Long Horizons

National Origin and the Skills of Imigrants in the Postwar Period

$01 / 91$

$01 / 91$

Stochastic Devaluation Risk and the Emirical Fit of Target Zone Models

Ieaming by Doing and the Dynanic Effects of International Trade

$01 / 91$

$01 / 91$

Is the Gasoline Tax Regressive?

$01 / 91$

Is Europe an optinum currency Area?

$01 / 91$

Alternative Aprroaches to MacroEconomics: Methodological Issues and

$01 / 91$ the New Keymesian Economics

Hunan Capital, Technology, and the Wage Structure: What do Time Series Show?

$01 / 91$

Assessing the Productivity of Inform- 01/91 ation Tectnology Equipment in U.S. Manufacturing Industries

Should the Holding Period Matter for Intertemporal consumption-Based CAPM?

$01 / 91$

Price-cost Margins, Exports and Productivity Growth: With an Application to Canadian Industries

$01 / 91$

From Inertia to Megainflation: Brazil $01 / 91$ in the 1980s

Precautionary Motives for Holding $\quad 01 / 91$ As sets

Erployer Size and Dual Labor Markets 01/91

Equilibrium in Competitive Insuranoe $\quad 01 / 91$ Markets With Moral Hazards 
Number Anthor

3589 Alan J, Allerbach Jagadeesh Gokhale Laurence J. Kotlikoff

3590 Frederick D.S. Choi Richard M. Ievich

3591 John H. Cochrane

3592 Patric H. Hendershott Janes A. Waddell

3593 Alan L. Oustman Thomas L. Steirmeier

3594 Luis A. Rivera-Batiz Paul M. Romer

3595 Stanley Fischer

3596 Hans-Ferner Sim

3597 Peter M. Garter

$3598 \quad$ Iaurence Kotliloff Bernd Raffellueschen

Torsten Persson Guido Tabellini

3600 Joshua Aizerman

3601 Francisco Delgado Bernard Dumas

3602 David Card
Title

Date

Generational Accounts - A Meaningful

Alternative to Deficit Acoounting

$01 / 91$

Intemational Acoounting Diversity:

Does It Impact Market Participants?

$01 / 91$

Volatility Tests and Efficient Markets: 0I/91 A Review Essay

The changing Fortumes of FHA's Mutual Mortgage Insurance Fund and the

$01 / 91$ Legislative Response

The Effects of Pensions and Retirement 01/91 policies on Retirement in Higher Ecucation

International Trade and Endogenous Technological change

$01 / 91$

Money, Interest and Prices

$01 / 91$

Macroeconcrivic Aspects of German

$01 / 91$

Unification

Alexander Hamiltan's Market Based Debt 01/91 Reduction Plan

How Regional Differences in Taxes and 01/91 Public Goods Distort Life cycle Location choices

Is Inequality Harmful for Growth? Theory and Evidence

Trade Reforms, credibility, and $01 / 91$ Development

Target Zones Big and Small

Intertemporal Labor Supply: An
$01 / 91$

$01 / 91$

01/91 Assessment

Copies of the above working papers can be obtained by sending $\$ 3.00$ per copy if requested within the continental U.S.; \$4.00 per copy for all other locations to Working Papers, NBER, 1050 Massachusetts Avenue, Cambridge, MA 02138. Advance paynent is required on all onders. Please make checks payable to the National Bureau of Econcmic Research. 